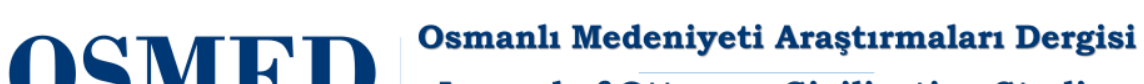 Journal of Ottoman Civilization Studies

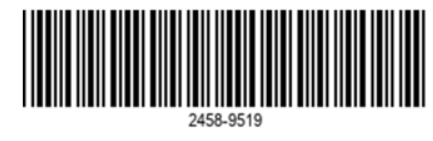

\section{Asır Osmanlı Ulemasında Siyaset - İlim İlişkisi: Birgivî Örneği}

The Relationship of Politics and Science Among XVIth. Century Ottoman Ulema: The Example of Birgivi

\section{Osman Cengiz}

Dr. Öğretim Üyesi

Pamukkale Üniversitesi

Tarih Bölümü

cengiz.osman@hotmail.com

ORCID ID: 0000-0001-8143-5388

\section{Makale Bilgisi / Article Information}

Makale Türü / Article Type : Araştırma Makalesi

Geliş Tarihi / Received : 18 Eylül 2021

Kabul Tarihi / Accepted : 14 Ekim 2021

Yayın Tarihi / Published : 15 Ekim 2021

DOI Number : 10.21021/osmed.997217

\section{Kaynak Gösterme / Citation}

Cengiz, O. "XVI. Asır Osmanlı Ulemasında Siyaset - İlim İlişkisi: Birgivî

Örneği". Osmanlı Medeniyeti Araştırmaları Dergisi, 13 (2021): 169-187. 


\title{
XVI. Asır Osmanlı Ulemasında Siyaset - İlim İlişkisi: Birgivî Örneği
}

\author{
The Relationship of Politics and Science Among XVIth. Century Ottoman Ulema: The Example of Birgivi
}

\section{Osman Cengiz}

$\ddot{O} z$

XVI. Asır, Osmanlı düşüncesinin klasik şeklini aldığı bir süreci kapsamaktadır. Osmanlılar İznik Medresesi ile birlikte Maveraünnehir ve Mısır gibi ilmî havzalarla daha sıkı bir ilişki içinde olmuştu. XV. Asır sonrasında ise bilim ve düşünce alanında kendi kimliklerini kazandılar. XVI. asır alimi olarak Birgivî'nin, çağdaşları Ebussuûd ve Çivizâde'ye kıyasla ürettiği düşünce onun bürokrat olmamasıyla da ilgiydi. Onun idareye mesafesi ve siyasete karşı olumsuz tavrı, çoğunlukla kassâm-ı askerîlik vazifesi sırasında edindiği tecrübeye dayanmaktadır. Sokullu Mehmed Paşa'yı bazı meselelerde ikaz ettiği bilinmektedir. Siyaset ve ilim ilişkisinde onu öne çeken ana konu ise vasiyetsiz para vakfına itiraz etmesidir. Bu konuda Ebussuûd ile münakaşaya girmiştir. Ilim tasnifinde ise Gazzalî’den etkilendiği anlaşılan Birigvî'nin Tarîka'daki tasnifi klasik sınıflamalardan farklılaşmaktadır. Kelam ilmine karşı temkinli yaklaşımı, tıp ilmini ve tedavi olmayı çok gerekli ve farz bulmaması şüphesiz ki onun zühd ve tasavvuf anlayışının yansıması olarak yorumlanabilir. Bu çalışma Birgivî Mehmed Efendi'nin Osmanlı idaresi ve ilmî birikime karşı tavrını ortaya koymayı ve ilk devirlerdeki ve ayrıca onun ilişkide olduğu ilmî çevredeki ulema-siyaset bağına değinmeyi amaçlamaktadır.

Anahtar Kelimeler: Osmanlı Uleması, Birgivî, Ebussuûd, XVI. Asır Osmanlı Düşüncesi.

\section{Abstract}

XVI. The century covers a period in which Ottoman thought took its classical form. Along with the Iznik Madrasa, the Ottomans had a close relationship with scientific basins such as Transoxiana and Egypt. After the XV th. century, they gained their own identity in the field of science and thought. As a XVI th. century scholar, the thought that Birgivî produced compared to his contemporaries Ebussuûd and Çivizâde was also related to the fact that he was not a bureaucrat. His distance from the administration and his negative attitude towards politics are mostly based on the experience he gained during his service as a qassâm asqery. It is known that he warned Sokullu Mehmed Pasha about some issues. The main issue that draws him to the fore in the relationship between politics and science is his objection to the money foundation. He had an argument with Ebussuud about this issue. In the classification of science, Birgivî's classification in Tarîka, which is understood to have been influenced by Gazzali, differs from the classical classifications. His cautious approach to theology and his disapproval of medical science and treatment are undoubtedly positioned as a reflection of his understanding of asceticism and mysticism. This study aims to reveal Birgivi's attitude towards the Ottoman administration and scientific accumulation, and to approach the ulema-politics link in the scientific circle.

Keywords: Ottoman Ulema, Birgivi, Ebussuud, XVI. Century Ottoman Thought 


\section{Giriş: Siyaset ve Ulema}

Osmanlı uleması ve ulema vezirler, devletin işleyişinde ilk devirlerden beri etkin bir rol üstlenmiştir. Özellikle ilk medresenin İznik'te Sultan Orhan tarafından kurulması ve buraya baş müderris olarak Davud Kayserî’nin atanmasından önce siyasetin bilimle olan serüveni çoktan başlamıştı. Osmanlılarda tedrîs, kazâ ve iftâ gibi alanların ayırımı ve protokol biçimleri Fâtih Sultan Mehmed'in teşkilat kanunnamesinde görülmektedir. I. Murad devrinde Bursa kadısına kazasker ünvanı verilmişti. Gelibolulu Mustafa Âlî, Molla Yegân'ın, Molla Fenarî'den sonra "medrese ve fetvâ ve Bursa kazâsına mutasarrıf” olduğundan bahsetmektedir'. İstanbul'un fethinden sonra II. Mehmed, İstanbul kadıs1 ile kazaskerin görevlerini ayırmış $^{2}$ ve başkent müftüsü Fatih Kanunnamesi'nde şeyhülislam ve ulemanın reisi olarak anılmıştır ${ }^{3}$. Benzer biçimde Kanûnî döneminde de Ebussuûd Efendi başşehir müftüsü olarak ilmiyenin reisidir ve kazaskerler onun ardında kalmıştır ${ }^{4}$. Fatih Sultan Mehmed, Çandarlılar gibi güçlü Türk ailelerine mensup vezirleri tasfiye etmiş onların yerine devşirmeleri geçirmişti. Fatih'in bu tasfiyesi siyasi alanla sınırlı kalmamış ve Çandaroğulları'ndan hiç kimse ilmiye sınıfına sokulmamıştı ${ }^{5}$. Ulema, Osmanlıların sonraki yüzyıllarında gittikçe daha büyük bir ehemmiyet kazandı. Zira ulema sınıfı her kesim için bir meşruiyet aracıydı. Padişahın fermanı, fetva ile güçleniyor; isyanlar ve darbeler dahi fetva ile meşrulaşıyordu. XVI. asra kadar çoğunlukla fetva, fermandan bağımsız iken bu yüzyılda Çivizade'nin para vakfını yasaklayan fetvası için hatt-1 hümayun çıkartması ve Ebussuûd'un Maruzât'ının fermanla tatbikinin sağlanmasında olduğu gibi fetvanın, ferman ile genel bir uygulama haline getirilmesine dair örnekler vardır ${ }^{6}$. XVII. yüzyıla kadar daima yükselen trentte bir nüfuza sahip olan ulemanın, bu yüzyılda siyasî gücü hissetme ve kullanma temayülüne girdiği anlaşılmaktadır. Zira bu dönemde ulemanın siyasete olan ilgisinin fazlalaştığ gözlenmektedir. I. Ahmed'le başlayan süreçte her zümre kendi güç ve etki alanını kuvvetlendirmek için ulemayla sıkı bir ilişki içine girmiştir ${ }^{7}$. Başarılı olan isyanlardan sonra asiler ve darbeciler, kendi hayatlarını garantiye almak gayesiyle önde gelen ulemanın imzalarının bulunduğu hüccetler hazırlatmıştı. Bu geleneğin ilk defa II. Bayezid döneminde başladığı ve sonraki isyanlarda da icra edildiği kaydedilir ${ }^{8}$.

Osmanlılarda coğrafya, tıp ve matematik gibi alanlardaki bilimsel gelişmeler, XVI. yy. sonrasında da devam etmekte ve Avrupa takip edilmekte ise de Avrupa'dakine benzer bir ilişki ağının Osmanlı'da bulunmaması bir yana, Avrupa'daki değişimin, memalîk-i mahrûse'de gerçekleşmemesinin sebepleri farklıyd ${ }^{9}$. Avrupa'da bilim üretimi ve bilimsel faaliyet öncelikle burjuva ve onun biriktirip temin ettiği sermaye ile sıkı ilişki içindeydi. Burjuvanın, desteklediği bilimsel çalışmanın ürünü olan ve sonraları patent ve telif hakkına sahip olacak olan imtiyazlı bilgi vasıtasıyla elde ettiği kazanç, kraliyetin karşısına daha güçlü çıkmasını ve onunla masaya oturmasını temin etmişti. Böylece, bilimsel gelişme, birikmiş sermaye ve merkezi yönetim, arasında ortaya çıkan bu üç taraflı ilişki, çoklu menfaatlerin güdülenmesiyle hızlı bir değişim ve dönüşüme neden oldu. Osmanlı ülkesindeki bilimsel çalışmalar ise özellikle XVI. asırdan sonra

\footnotetext{
${ }^{1}$ Gelibolulu Mustafa Âlî, Künhü'l-ahbâr, Tıpkı Basım, (Ankara: Kültür Bakanlığı, 2009), 82a.

2 ilber Ortaylı, Hukuk ve Idare Adamı Olarak Osmanlı Devleti’nde Kadı, (İstanbul: Kronik Yayınları), 2016, s. 25.

${ }^{3}$ Akgündüz, Osmanlı Kanunnameleri, I (İstanbul: Fey vakfı, 1990), 318.

4 Illber Ortaylı "Kadı" TDV İslam Ansiklopedisi, XXIV, 70.

5 Yücel Öztürk “Osmanlı Klasik Sisteminin Teşekkülü ve Çözülüşü” Türkiye Günlüğü, Sayı 58, Kasım-Aralık, 1999, (133-149), 137. Ayrıca bkz. Hüseyin Yılmaz, "Osmanlı Tarihçiliğinde Tanzimat Öncesi Siyaset Düşüncesine Yaklaşımlar" Türkiye Araştırmaları Literatür Dergisi, Cilt 1, Sayı 2, 2003, (231-298), 289-290.

${ }^{6}$ Krş. İnalcık, Kuruluş ve imparatorluk Sürecinde Osmanlı: Devlet Kanun, Diplomasi, (İstanbul: Timaş Yayınları, 2019), s. 58; Mumcu, Osmanlı Devleti'nde Siyaseten Katl, (İstanbul: Phoenix Yayınları, 2017), s. 92-96.

7 Bu durum, siyasî tavır üzerinden ulemanın farklı taraflarda yer almasına ve onların siyasi mücadele içinde yıpranmasına neden olmuştur. Bkz. Mehmet Ipşirli, “Osmanlı Uleması” Osmanlı, VIII (Ankara: Yeni Türkiye Yayınları, 1999), s. 71.

8 Erhan Afyoncu, Ahmet Önal ve Uğur Demir, Osmanlı Imparatorluğu’nda Askerî İsyanlar ve Darbeler, (İstanbul: Yeditepe Yayınları, 2016), s. 29.

${ }^{9}$ Krş. Ekmeleddin Ihsanoğlu "Osmanlı Bilimine Toplu Bakış" Osmanlı, VIII, 21-23.
} 
hem sermaye birikiminden hem de merkezî yönetimin teşvik ve güdümünden bağımsız gelişmiş ve önceki asırlardakine benzer bir gelenek oluşturamamıştır. Zira siyaset ve devlet perspektifi XVI. yy. sonrasında içe kapanmaya başlamış; kelam, fikıh ve tasavvuf birlikteliğinde aklî yetkinliği temel alan refleks, bu bilimlerin ayrışmasıyla statik din anlayışını artırmıştı. Esasen bu durumun, ilmî ve fikrî zihniyet problemi olduğu aşikardır. Böylece Osmanlılar, siyaseten din ve bilim veya vahiy ve akıl arasında tercih yapmak gibi XVI. asrın ikinci yarısına kadar klasik dönemde hiç denenmemiş bir tecrübeyi yaşadılar. Bununla birlikte XVIII. yüzyıl ve sonrasında Avrupa'ya ait bilgi ve bilimler, toplumsal sorunlara bir çözüm çabası olarak değil devletin bekasına hizmeti açısından dikkat çekmiş ve ithal edilmiştir ${ }^{10}$.

Şah İsmâil'in Anadolu'daki faaliyetlerini yoğunlaştırdığ1 bir süreçte Yavuz Sultan Selim'in Sarıgörez/Sarıgürz Nûreddin Efendi'den aldığ 1 fetva ${ }^{11}$ ve Kemalpaşazâde'nin Risâle fì tekfiri'l-revâfiz gibi eserleri $^{12}$ ayrıca Şeyhülislâm Ebussuûd Efendi'nin verdiği fetvalar, dönemin siyasi hassasiyet noktalarına işaret etmektedir. Ebussuûd Efendi'nin kızılbaşlarla ilgili vermiş olduğu fetvanın içeriği ${ }^{13}$ Kemalpaşazâde'nin fetvaları ile benzerdir. Ebussuûd Efendi, kızılbaşların İslâm'ı hafife aldıkları, haramı

10 Dolayısıyla bilimle uğraşan kimse ve kurumların, daha çok siyasî kimlik taşımaları (Encümen-i daniş ve Meclis-i maârif-i umumiye üyeleri, Said Halim Paşa, Prens Sebahattin vs.) bilim-merkezî yönetim ilişkisini güçlendirse de sermaye birikimi üzerinden işleyen ticaret-bilim ya da kar-merak ortaklığının yeri, Osmanlı'da hala boş durmaktaydı. Korkut Tuna "Osmanlı Batılılaşma ve Bilimler" Osmanlı, 8/56-57. Günümüzde de benzer bir durumun devam ettiğini söylemek yanlış olmamalıdır. Zira bugün bizler Avrupa'daki gelişmelerden haberdarız. Neyi nasıl yaptıklarını da biliyoruz. Buna rağmen benzer bir altyapıyı ve Ar-Ge sistemini kurmakta bazen gönülsüz oluyoruz.

11 Yavuz Dönemi (1512) Şeyhuşlislamı Sarıgörez'e ait fetva metni şöyledir: “Müslümanlar bilün ve âgâh olun, şol tâyife-i Kızılbâş ki reisleri Erdebiloğlu İsmail'dür Peygamberimizün aleyhi's-salât ve's-selâm şerîatini ve sünnetini ve din-i İslam ve ilm-i dini istihfâf ettikleri ve dahî Allahü Teâla haram kıldığı günahlara helaldür didükleri ve istihfâfları ve Kur'an-ı azîmi ve Mushafları ve kütüb-i şerîati tahkîr idüb oda yakdukları ve dahi ulemâya ve sülehâya ihânet [تهان-tahkir?] idüb kırub mescidleri yıkdukları ve dahi reisleri laîni ma'bud yerine koyub secde itdükleri ve dahi Hazret-i Ebîbekr'e radıyallahu anh ve Hazret-i Ömer'e radıyallahu anh söğüb hilafetlerini inkâr itdükleri ve dahi peygamberimüzün hatunu Ayişe anamuza (radıyallahu anhâya iftira idüb) söğdükleri ve dahi aleyhi's-salât ve's-selâm şer'ini ve din-i İslamı götürmek kasdın itdükleri bu zikr olunan ve dahi bunların emsâl-i şer'e muhalif kavilleri ve fiilleri bu fakir bâkî ulema-yı dini İslam katlarında (tevâtürle) malum ve zahir olduğı sebebden biz dahi şeriatün hükmi ve kitaplarımuzun nakli ile fetvâ verdük ki ol zikr olunan tâyife kâfirler ve mülhidlerdür ve dahi her kimse ki anlara meyl idüb batıl dinlerine razı ve muâvin olalar anlar dahi kâfir ve mülhidlerdir bunları kırub cemaatlerin dağıtmak (cemi Müslümanlara) vâcib ve farzdur. Müslümanlardan ölen saîd ve şehîd cennet-i a'lâdadur ve anlardan ölen hor ve hakir cehennemün dibindedür. Bunların hali kâfirler halinden eşedd ve ekbahdur. Zira bunların boğazladukları ve dahi saydları gerekse doğanla ve gerekse ok ile ve gerekse kelb ile olsun murdardur ve dahi nikâhları gerekse kendülerden ve gerekse gayrden alsunlar batıldur ve dahi bunlar kimseden miras yemek yokdur ve (bir nahiye ehli ki bunlardan ola) Sultan-ı İslam eazzellahu ensârahu içün vardur ki bunlarun (ricallerin katl idüb) mallarını ve nisalarını ve evlatlarını guzât-ı İslam arasında kısmet ile ve bunlarun ba'de'l-ahz tevbelerine ve nedametlerine iltifat ve itibar olunmayub katl oluna ve dahi bir kimse ki bu vilayette olub anlardan idüğü biline veyahut anlara giderken tutula katl oluna ve bi'l-cümle bu tayife hem kâfirler ve mülhidlerdür ve hem ehl-i fesadur. İki cihetten katilleri vacibdür Allahumme'n-sur men nasara'dîn, ve'hzul men hazele'l-müslimîn. El-Müftî ez'afü'l-ıbâd Hamza el-fakîr eş-şehîr bi-Sarugörez" Topkapı Sarayı Müzesi Aeşivi, nr.6401, M. C. Şehabeddin "Tekindağ, Yeni Kaynak ve Vesikaların Işığı Altında Yavuz Sultan Selim'in İran Seferi” iü Edebiyat Fak. Tarih Dergisi, c.XVII, s.22, Mart, 1967, 54-55. Ayrıca bkz. Mehmet Özkan, Balıkesirli Bir Osmanlı Alimi: Sarı Gürz Nureddin Hamza Efendi (ö.928/1522) ve el-Murtazâ Adlı Eseri", Milli Mücadele’nin 100. Yılında Kuva-yı Milliye Şehri Balıkesir Uluslararası Sempozyumu Bildiri Kitabı (19-22 Eylül 2019), Editörler: Prof. Dr. Zeki Çevik, Prof. Dr. Kamile Gülüm, Prof. Dr. Birsel Oruç Aslan, Arş. Gör. Hasret Ulusoy Yıldırım, Balıkesir Büyükşehir Belediyesi Kent Arşivi Kültür Yayınları No: 16/2, Nisan 2020, c.II, s. 504.

12 Vejdi Bilgin, Fakih ve Toplum -Osmanlı'da Sosyal Yapı ve Fıkıh, (ístanbul: İz Yayınları, 2003), s. 128-130.

13 “Ol zalimler Kur'an-ı Azîm'i şeriat-ı şerîfeden İslâmı tahfîf eylemekle ve kütüb-i şer'iyye-i tahkir edüb oda yakmak ile ve ulemâ-i dinî ilimleri içün ihanet edüb kırmak ile ve reisleri olan fâcir mel'ûni ma'bud yerine koyub ana secde eylemekle ve dahi hürmeti nusûs-ı kat'iyye ile sabit olan muharremât-ı diniye-i istihlal etmekle ve Hazret-i Ebibekr ile Hazret'i Ömer'e radıyallahu anhumaya Ia'n eylemekle kâfir olduklarından sonra Hazret-i Aişe-i sıddıkanın radıyallahu anhâ berâeti ve nezâheti bunca âyât-ı azîme nâzil olmuş iken anlara itâle-i lisan eylemekle Kur'ân-ı Kerîm'i tekzîb edüb kâfir olduklarından gayri Hazret-i Risâletin sallellâhu aleyhi ve sellem cenab-ı azizlerine şîn getürdükleri ile sebb-i nebi eylemiş olub cumhûr-i ulemâ-i a'sâr ve emsâr icmâ'ı ile katilleri mübah olub küfürlerinde şek edenler kâfir olurlar" Pehlül Düzenli, "Osmanlı Hukukçusu Ebussuûd Efendi ve Fetvaları", Doktora Tezi, Selçuk Üniv.ersitesi, 2007, s. 146. 
helal saydıkları için Ehli Sünnet dışı sapık firkalardan biri saymış ve öldürülmelerini helal görmüş ${ }^{14}$ ve onlarla savaşarak bu uğurda şehit olmanın gazâ-i ekber ve şehâdet-i azîme olduğunu vurgulamıştır ${ }^{15}$. Osmanlı'da Şeyhlikten şahlı̆̆a geçme heves ve arzusu fark edilen veya böyle yorumlanan bazı âlimler, devlet tarafindan siyasî tehdit olarak algılanmışlar ${ }^{16}$ bu sebeple Gülşenî, Hamzavî ve Bayramî gibi ekollere bağlı batınî ve ibahî görüşlere sahip kabul edilen bazı mutasavvıflar mülhid veya zındık olmakla itham edilmişler veya takibata uğramışlard ${ }^{17}$.

Ebussuûd, kadı'nın hükmünün tartışılmasını veya onun aldığı kadılık ücretlerinin dile dolanmasının siyaseten mazur görmemiş̧ir. Zira bu tavır, devlette karşı bir zaaf oluşturacak ve otoriteyi sorgulatacak bir teşebbüs olarak konumlanmaktadır. Usulüne uygun görülmüş bir davadan sonra tarafların fazladan huccet istemeleri üzerine her bir kâğıt için ayrı ücret almanın makul olduğunu "haram denilmez, kağıld mülkî olub bey' etmiş olur" diyerek cevaplamış ardından ise "Bu surette bazı kimesler kadiya, senin ziyade huccet içün aldığın rüşvetdir. Alınan akçe kanundan ziyadedir haramdır, dese haramdır diyen zeyde şer'an ne lazım gelir? Sorusuna "Helale haram demiş olur, (kâfir olur)"18 şeklinde cevap vermiştir. Osmanlı Devleti'nde müftüden fetvâ ve kadıdan hüccet almak için "akçe ödenmesi" yerleşik bir uygulamadır" ${ }^{19}$.

14 Ebussuûd’un Kıbrıs Seferi, kızılbaşlar ve Şehzade Bayezid ile ilgili fetvaları bu dönemde siyasî alanda ulemanın rolüne verilebilecek örneklerdendir. Bkz. Abdullah Demir, Şeyhülislam Ebussuûd Efendi: Devlet-i Aliyye'nin Büyük Hukukçusu, s. 64-70; Imber, Şeriattan Kanuna, s. 96.

15 Düzdağ, Ebussu'ûd Efendi Fetvaları Işığında 16. Asır Türk Hayatı, (İstanbul: Enderun Kitabevi, 1983), 109 (f.479).

${ }^{16}$ Melamî şeyhlerin mehdîlik davalarında bu durum açıkça görülür. Ocak, Osmanlı Sufiliğine Bakışlar, s. 168-173. Ayrıca bkz. Ocak, Yeniçağlar Anadolu'sunda İslam'ın Ayak izleri-Osmanlı Dönemi, s. 72-81.

${ }^{17}$ Bu noktada Çivizâde'nin kaleminden çıkan şu satırlar mühimdir: Şeyh ibrahim müridlerinin besmele ile zebh etdikleri şer'an helal mıdır? El-Cevab: Fî zamaninâ meşhur olan Şeyh ibrahim, Mısır'da fevt olup, Mederese-i Müeyyediyye kurbunda defn olunmuştur. Ânın halin, tafsîl üzere bilip, âna mürid olan zındıktır, milleti yoktur, zebîhasi hükm-i meyyitedir, helal olmaz. Şeyh Mehmed"17. "Zeydi âlim, "fî zemâninâ meşhur olan Şeyh ibrahim müridleri Yahûdî tâifesinden küfürde eşeddir. Zîrâ bunlar Rasulullah sallallahu aleyhi ve sellem nübüvvetine ve hem fazlına münkirlerdir. Ammâ Yahûdî tâifesinin ba'zı, Hazret-i Rasûlün nübüvvetine münkir, fazlına mu'terifdir. Ve ba'zı hem nübüvvetine ve hem fazlına mu'terifdir, "Iakin nübüvveti Arab'a mahsustur" der" dese şer'an Zeyd'e ne Iazım olur. El-Cevap: Nesne lazım olmaz. Çivizâde. İbnü'l-Edhemî, Mecmûa-i fetâvâ, Süleymaniye Ktp. Atıf Efendi Kütüphanesi, 2835. vr. 9a. Bu mesele sonradan Ebussuûd'a şu şekilde sorulmuştur: A'zam-ı ulemâ-i dîn ve a'lem-i fuzelâ-i râh-i yakîn, bu mesele tahkikinde ne buyururlar ki: Zeyd dese ki "Mısır'da, câmi'-i Müeyyediye kurbunda medfûn olan Şeyh ibrâhim Gülşenî ve ana mürîd olanlar ve i'tikad edip muhabbet eyleyenler külliyen mülhidlerdir ve zındıklardır. Merhum Çivizâde fetvâsı bu hususta bize kâfidir. Anların imâmetleri câiz değildir ve anlara i'tikâd eylemek hatâdır ve ana mensub olanlar dâll ve mudill ve zebîhaları haramdır" dese, Amr mukâbelede dese ki "bu sözü mutlak söyleme, beyt: Sırr-ı dill[râ] her bende-i hodâ nemîdâned / Hod-râ to der-în miyâne enbâz mekon! [Her Tanrı kulu gönül sırrını bilmiyor. Kendini sen, bu arada ortak yapma!] "hel şekakte kalbehû" hadîs-i şerîfiyle amel evlâdır. Bu kavmin küllîsi sen dediğin gibi değildir. Zirâ Şeyh ibrâhim'i gördüm, mirâren nasîhatını dinledim. Ol azîz Ehl-i sünnet i'tikâdı üzre idi ve âbid ve zâhid ve ehl-i takvâ ve hak yolunda âşık ve sâdık idi. Ve Müslümanları hevâ-i nefse tâbi' olmadan nehy edip, şer'-i serîf muktezâsı ile amel eyleyip, selef-i sâlihîn tariki üzre halkı doğru yola irşâd eylemekte cidd ü himmetin sarf eder kimse idi. Hattâ Pâdişâh hazretleri (zâdellâhu umrahû) cânibinden ol azîzi Mısır'dan Istanbul'a getirdiler, ahvâli kemâ yenbağî tefahhus olunup cemîi etvârı şer'-i şerîfe muvâfık bulunmuştur. Çivizâde yalnız ânın hakkında bed-gümân olmamıştır, Şeyh-i ekber Şeyh Muyiddin-i Arabî ve Şeyh Ömer ibnü'l-Fârız ve Molla Hudâvendigâr (kaddesallahu esrârahum) ve sâir meşâyihten çok kimselere sû-i zan etmiştir, anın re'yi bize delil olmasa olur, zirâ mutlak söyleyip, selb-i küllî eylemiştir. Bu tâifenin içinde hod zâhiri ve bâtını şer'i şerîfe muvafık, sünnî ve dindar ve ehl-i sülûk ve perhizkâr nice 'âbid ve zâhid ve âlim ve nâsih mü'min ve müttaki kimseler vardır. Ve anlara i'tikad edip muhabbet eden Müslümanlar hadden birun ve adeden efzundur. Eğerçi ol azîze mensub, geçinenlerin arasında mülâhide var ise, anlara ne itibar, şeyh ibrâhim kendi ârif ve kâmil ve vera' ve takvâya ve ilm-i ma'rifete mâil olmakla, mürid olanlarda akîdesi pâk kimseler çok ve zâhirî şer'a muhâlif kavilleri ve fiilleri olmayan halîfelerine ve muhiblerine ve müridlerine sû-i zan etmek lâyık değildir" dese, bu hususta Amr'ın sözü Şeyh ibrâhim ve ana mensub olanlar bi'l-külliyye tarik-i sedâddan ve istikâmetten ma'zûl müdür, bu hususta re'y-i sâ'ibiniz ne vechiledir? Şâfi Cevab buyurup, indallah me'cûr ve müsâb olasız. El-cevap: Ehl-i sünnet ve'l-cemâat itikadı üzre olup şer'-i şerif muktezâsınca amel edip selef-i sâlihîn tarikine sâlik olan ${ }^{17}$ kâinen mâ kân makbuldür. Şeyh ibrâhimlidir demekle onlara dahl ve taarruz câiz değildir" Düzdağ, Age, s. 192-193.

18 Ebussuud, Duâname-i Ebussuûd, İBB, Atatürk Kitaplığı, Belediye, K0792, 14b.

${ }^{19}$ Atçıl, Procedure in the Ottoman Court and the Duties of Kadis, 20. Onun bir devlet adamı ve dost olarak Kanunî ile yakınlığı, Süleymaniye Camii'nin temeli atılacağı zaman (27 Cemâziyelevvel 957 Cuma/13 Haziran 1550) Kanûnî́ye refakat ederek ilk temel 
Ebussuûd'un fetvalarıyla hukuku daha işlevsel ve devlete daha faydalı kılmaya çalıştığı bilinmektedir ${ }^{20}$. İște tam bu noktada fıkhî metinlere aykırı görülüp meşruiyetine fetva verilen bazı uygulamalar, özellikle Ömer Lütfi Barkan tarafından şer' ̂́leştirme olarak yorumlanmıştır. Esasında yapılan işlem, devletin öteden beri sürdürdüğü bir uygulamanın veya önceden ortaya çıkmayıp belli bir zaman sonra devletin yürürlüğe koymak istediği uygulamalara Şeyhülislam fetvasıyla meşruiyet kazandırılmasıdır. Bu çerçevede sorunun, fikhî metinlerin veya "şer'î algının" istediği biçimde değil Osmanlı Türk-Moğol geleneğinin arzu ettiği biçimde çözümlendiği kaydedilmiştir. Bu yoruma göre burada bir şer'îleştirme değil aslında örfîleştirme söz konusudur. Bu takdirde Osmanlı'nın, geleneksel fikıh anlayışına uymadığ 1 fakat onu kendi tevarüs ettiği siyasî tarihî mirasa uydurduğu yorumu yapılabilir ${ }^{21}$. Bu duruma kardeş katlii², para vakıfları, yargıdaki işkence biçimleri vs. misaller çokça verilen örnekledendir ${ }^{23}$.

Siyaset ve ulema ilişkisi itibariyle XVI. yüzyılın kanun düzenlemelerinde bürokrat ulema kimliği bakımından iki isim öne çıkmaktadır: Şer'î hukuk sahasında Ebussuûd ve örfî hukuk sahasında ise Celalzâde Mustafa Çelebi24 ${ }^{2}$. XVI. yüzyılda bir nişancıda aranan başlıca iki özellik, resmî yazışmaların inşâsında ustalık ve devlet kanunlarında uzmanlıktı. Yirmi üç yıl aralıksız olarak nişancı olan Mustafa Çelebi bu vasıfları haizdii ${ }^{25}$. Çivizâde'nin bazı fetvaları, hukuk-siyaset ilişkisine atıf yaparak toplumsal kaos ve adalet bağını kurma biçimini gösterdiği gibi, bu ilişkiyi yorumlama şeklini de yansıtır. Bu metinlerde

taşını, gelenek olduğu üzere mihrap duvarının yükseleceği yere yerleştirmesiyle de örneklenebilir. Selçuk Mülayim "Süleymaniye Camii ve Külliyesi" DiA, 38/114; Cavid Baysun "Ebüssuûd Efendi" iA, 4/93. Kanûnî’nin, Sigetvar seferinde iken, İstanbul muhâfızı İskender Paşa ile birlikte idâreye nezâret etmesi için İstanbul'da bıraktığı Ebussuûd Efendi'ye duâ talebinde bulunduğu meşhur mektup ise şöyledir: "Hâlda hâldaşum sinde sindaşum âhıret karındaşum tarîk-ı hakda yoldaşum Monlâ hazretlerine du'â-yı bîhadd iblâgından sonra nedür hâlünüz ve nicedür mizâc-ı lâzimü'l-imtizâcunuz sıhhat u 'âfiyetde midür. Hazret-i Hakk celle şânuhû hızâneyi hafiyyesinden kemâl-i kuvvet ve nihâyetde selâmet müyesser eyleye. Niyâz olınur ki evkât-ı müteberrikede bu muhlislarını kalb-i şerîflerinden iz'âc itmeyeler ola ki küffâr-ı hâksâr münhezim ü mükedder ola 'asâkir-i islâm mansûr u muzaffer olup rızâ-yı ilâhîye muvâfık 'amel ola. Summed-du'â bende-yi Hudâ Sultân Süleymân" Abdülkadir Dağlar, "Türkçe Mektupları Işığında Ebussuûd Efendi'nin Beşerî Münâsebetleri”, Osmanlı Araştırmaları / The Journal of Ottoman Studies, XLI (2013),279-320, s. 292.

20 Joseph Schacht, islam Hukukuna Giriş, çev. Mehmet Dağ-Abdülkadir Şener, (Ankara, 1986), s. 98.

${ }^{21}$ Bunun belki de en dikkat çeken örneği hanedan üyelerinin öldürülmesi meselesidir: "Genel olarak isyan eden hanedan üyeleri öldürülürler. Bununla beraber ağır bir suç işlemedikleri takdirde hanedan üyelerinin katledilmemeleri son derece dikkate değer. Türk-İslam devletlerinde suçsuz hanedan üyelerinin öldürülmesi bilhassa Anadolu Selçukluları'nda geniş ölçüde görülmeğe başlamıştır". Mumcu, Osmanlı Devleti'nde Siyaseten Katl, s. 169. Ayrıca bkz. s. 174.

22 Timur'un "hanedan üyelerinden birisinin tahtta hak iddia etmesi (yani isyan etmesi) durumunda, bu görüşünden vazgeçinceye kadar hapsedilmesini emretmesi" gibi farklı uygulamalar da olmuştur. İlgili hüküm şöyledir: "Emrettim ki eğer öz oğullarımdan herhangi biri saltanat talebinde bulunarak başkaldırırsa, onu vurup-dövüp öldürmeye veya azalarından birine zarar vermeye kimse cüret etmesin. Lakin bu yolundan geri dönünceye kadar onu tutuklukta saklasınlar ki bu iş halk içinde bozgunluğa yol açmasın". Timur'un Günlügü: Tüzükât-ı Timur, İstanbul, 2014, 92; Cüneyt Kanat, Ortaçağ Türk Devletlerinde Suç ve Ceza, (İstanbul: Küre yayınları), 2017, s. 61. Bununla birlikte A. Ahat Andican, Tüzükât’ın iç metin tutarsızlıkları ve diğer kaynaklarla bazı uyumsuzlukları sebebiyle Timur'a ait olmadığı ve on yedinci yüzyılda kaleme alındığı vurgusunu da buraya not edelim. A. Ahat Andican, "Tüzükât-ı Timurî Gerçek mi ve Geçerli bir Birincil Tarihî Kaynak Olarak Kullanılabilir mi?” Türkiyat Mecmuası, c. XXVII, 2, 2017, 33-83. Bununla birlikte İnalcık'ın görüşü şudur: "Kim toplamış olursa olsun Tüzükât-ı Timurî gibi eserler eski Türk-Moğol devlet geleneği ile ilişkilendirilebilir." İnalcık, Osmanlı'da Devlet, Hukuk, Adalet, s. 58.

${ }^{23}$ Tartışılan diğer başıklar ve modern tartışmalar için bkz. Muharrem Midilli, "Klasik Osmanlı Hukukundaki Şer'-Örf Ayrımına Dair Modern Tartışmalar", Türkiye Araştırmaları Literatür Dergisi, Cilt XII, Sayı 23, (2014), 33-48

24 Mehmet Akif Aydın "Ceza" TDV İslam Ansiklopedisi, VII, 481.

25 Peçevî Tarihi, haz., Bekir Sıtkı Baykal, I (Ankara: Kültür Bakanlığı yayınları, 1992) 34. Ferman, menşur, nâme gibi padişah adına çıkarılan yazılarda Celâlzâde'nin kullandığı hitaplar ve ifade biçimleri, en az XVII. yüzyılın ilk çeyreğine kadar Osmanlı bürokrasisinde örnek tutulmuştur. Snjezana Buzov'un ifadesiyle Kanunî devrindeki çalışmalar bir "tedvin (compilation), tahkim (consolidation) ve tanzim (systematization)" düzeyine ulaşmış bu da Celalzade Mustafa'nın Ebussuûd ile birlikte üstlendiği bir vazifeydi. İkisinin çabaları sayesinde kanunun hazırlanması ve uygulanması, Osmanlıların egemenlikle ilgili düşüncelerinin önemli bir ilkesi haline gelmişti. Kaya Şahin, Kanunî Devrinde Imparatorluk ve iktidar: Celalzade Mustafa ve 16. Yüzyıl Osmanlı Dünyası, çev. Ahmet Tunç Şen, (İstanbul: Yapı Kredi Yayınları, 2014), s. 255. 
mahkemenin dokunulmazlığına, sultanı temsil eden kadının ${ }^{26}$ saygınlığına gösterilmesi gereken özeni; meclis-i şer'a yapılmış bir saldırının en ağır biçimde cezalandırılacağını; ilmin âlimin yüceliğine yapılan atfı ve bütün bunlarla dinin sıkı ilişkisinin vurgulandığını görmekteyiz ${ }^{27}$. Çivizâde, askeri devletin bir rüknü olarak görür ve ona saygısızlık edilmesine müsaade etmez ${ }^{28}$. Çivizâde, dört halifeden Hz. Ali'yi daha fazla sevdiğini söyleyen kişiye "nesne lazım gelmeyeceğini” söylerken, devlet politikasının aksine Şiî-Safevî münakaşasına çekilebilecek bir konuyu, şaşırtıcı biçimde yumuşak karşıladığı söylenebilir ${ }^{29}$.

Esasen sadece fakihler değil özellikle tarihçiler de siyasetin merkezinde yer almışlardı. Fatih'in fetihlerini kaleme alan Tursun Bey, eserine "Sana Zülkarneyn'i [onun tarihini] soruyorlar. De ki: Size onun yaşadıklarını anlatacağım"30 ayetiyle başlayarak II. Mehmed'i Cihan hükümdarı manasını taşıyan Zülkarneyn ile ilişkilendirmiştiti ${ }^{31}$ Tursun Bey'in siyasî güç ve dinî misyonu birleştiren ve peygamberliği ihtilaflı bir karakter olan Zülkarneyn ile giriş yapmayı, Hz. Süleyman'a tercih etmesi, şüphesiz ki onun hükümdarlık yönünün ağır basması ve Fatih Sultan Mehmed ile daha çok uyuşmasıydı. "Yeryüzünde bir halife yaratacağım" ayetini zikreden Tursun Bey böylece retorik olarak, Kur'an'ın meşru saydığı siyasî ve askerî mülk yani hâkimiyet fikrini, Fatih'in şahsına izafe ediyordu. Başka tarih ve ahlak metinlerinde olduğu gibi Tursun Bey'in de Zülkarneyn'e bahis açması, Osmanlılar'ın düşünce dünyasının siyaset anlayışına atıf yaparak Peygamber Şeriatı ile Padişah Fermanı arasındaki tamamlayıcılık ilişsisini hatırlatmayı hedeflemektedir

\section{Birgivî’nin Siyaset Tasavvuru ve İdareye Mesafesi}

Birgivî Mehmed Efendi’nin (ö. 981/1573) doğumu için 929/1523 ${ }^{32}$ veya 926/1526 ${ }^{33}$ seneleri verilse de doğrusu kendi ağzından "Vilâdetüm tarihi dokuz yüz yirmi dokuz cemâziyelûlâsının onuncu günüdür" şeklindeki beyanı sebebiyle ilkidir ${ }^{34}$. Takıyyüddin veya Muhyiddin gibi elkabın ${ }^{35}$ onun vefatından sonra sevenleri tarafından verildiğini söylemek mümkündür. Yetiştiği asırda devrin alimleri ve idarecileri üzerinde etkili bir isim olan Birgivî Mehmed Efendi daha çok vasiyetsiz para vakfına karşı çıkmasıyla

26 Imber, Şeriattan Kanuna, s. 179. Mehmet Ali Ünal, Osmanlı Müeseseleri Tarihi, s. 109.

27 “Berât-ı şerîf ile kâdı olan Zeyd, mahkemesinde oturup icrây-ı şer' ederken bazı eşkıya bir yere cem' olup şehir içinde aydınlık zamanda gelip mahkemeyi taşa tutup, pencerelerin ve kapıların yaralayıp Zeyd-i kadıyı katl etmek kastedip, kadı dahi mahkemesin bırakıp yalın ayak başı kabâ eline bir seyf alıp kaçsa kadıya ne lazım gelir ve mahkemeye taş atan kimesnelere ne lazım gelir. Beyan buyurula. El-Cevap: Vallahu A'lem. Zeyd-i kadı kaçıp kurtulmak ile nefsin katilden halâs etmiş olur. Mahkemey-i şerifeye taş atan kâfirler katl olunmak lazımdır. Müslüman nâmına olup taş atılır. Kable'l-ahz tevbe ederlerse elleri kat' olunmak lazımdır. Ve tevbe ettiklerinden sonra tecdîd-i iman ve tecdîd-i nikâh gerektir. Eğer tevbe etmezlerse ânlar dahi kâfirlerdir. Katl olunmak lazımdır. Bu surette ol şehrin ulemâsına ve sâir halkına anda hazır bulunup, bakıp durup men etmeyenlere, "kadı zalim idi, hakkıdır, etti buldu" diyenlere ne lazım gelir? El-Cevap: Allahu A'lem. Hâşâ sümme hâşâ bu makûle kelimât eden kâfirden eşeddir. Tecdîd-i iman ve tecdîd-i nikâh lazımdır. Bu ihanet şer'-i mutahharayadır. Kadıya değildir. Min eyyi vechin kân ol kâfirlerin haklarından gelinmeğe iânet lazımdır. Ketebehu el-hakîr Muhammed ufiye anh" Fetâvâ-yı Veliyyüddin, Esad Efendi, nr. 1098, vr. 6b ve 195b'den naklen Ahmet Aydın, "Çivizâde Muhyiddin Mehmed Efendi'nin Fıkhî Görüşleri ve Fetvâları", Yüksek Lisans Tezi, Marmara Ünviversitesi, 2006, s. 144

28 "Zeyd-i nâib, kâfirin ve Müslümanların nikâhına izin veririm ammâ yeniçerinin nikâhına izin vermezim bunlar kâfirden eşeddir, dese Zeyd'e ne lazım olur? El-Cevap: Ta'zîr lazım olur. Çivizâde" ibnü'l-Edhemî, Mecmûa-i fetâvâ, vr. 14b

29 "Zeyd, câr-ı bârin [yârin] cümlesin severim ammâ Ali'yi artık (daha fazla) severim dese ne lazım olur? El-Cevap: Nesne lazım gelmez" Fetâvâ-yı Çorlulu Sinan b. Ramazan, Bayezid Ktp., nr. 2757, vr. 314a'dan naklen Ahmet Aydın, A.g.e., s. 208.

${ }^{30}$ Kehf Suresi 18/83.

31 Tursun Bey, Târih-i Ebu'l-Feth, 3; Mustafa Öztürk "Zülkarneyn” TDV Islam Ansiklopedisi, XLIV, 564.

32 Birgivî, Risâletü Inkâzi'l-Hâlikîn, thk ve tlk. Hüsâmuddin bin Musa Affâne, (Kudüs: Câmiatü'l-kuds, 2002), 15

33 İsmail Paşa Bağdâdî, Hediyyetü'l-Ârifîn Esmâü'l-Müellifîn ve Âsâru'l-Musannifîn, (Müssese tarih Ararabi: Beyrut, 1955), II/252; Mustafa Barçın, "Ünlü Alim İmam Birgivî” Sebîlürreşâd, Cilt XIV, Sayı 329, s. 59.

${ }^{34}$ Huriye Martı, Birgivî Mehmed Efendi, (TDV Yayınları: Ankara, 2011), 25.

35 Birgivî, Risâletü Inkâzi'l-Hâlikîn (Hüsâmüddin), 15. 
bilinmektedir ${ }^{36}$. Ömrünün sonlarına doğru kaleme aldığ es-Seyfü’s-sârim ’i (9 Zilkade 979/24 Mart 1572) vasiyetsiz para vakfetmenin câiz olmadığını ispat için telif eden Birgivî, ${ }^{37}$ Şeyhülislâm Ebussuûd Efendi'ye ve onunla aynı görüşü paylaşan Kadı Bilâlzâde'ye reddiye olarak yazmış ayrıca ücretle Kur'an okumanın ve bunun için para vakfetmenin caiz olmadığına dair İkâzü'l-Hâlikîn (967/1560) Îkâzü'n-Nâimîn ve Ifhâmü'l-Kasırîn (972/1565) risalelerini kaleme almıştır. Muaddilu's-salât (1567-68) ise ta'dîl-i erkân ile ilgili yazdığı bir eserdir. Ebussuûd'un, kendisinden otuz yaş kadar küçük olan Birgivî'ye para vakfı konusunda ikazda bulunduğu bilinmektedir ${ }^{38}$. Birgivî, Kızıl Molla lakabıyla tanınmış ve müderris olmadan önceki son hocas ${ }^{39}$ Abdurrahman Efendi'nin (ö.983/1575) öğrencisi olmuştur ${ }^{40}$. Abdurrahman Efendi'nin yanına mülâzım olup ihtisasını onun yanında tamamlayarak icazet alan ve müderrislik pâyesi elde eden Birgivî bir süre bazı medreselerde müderrislik yapmıştır. Onun çerçeve metin denebilecek en meşhur eserleri ise et-Tarîkatü'l-Muhammediyye ve's-sîretü'l-Ahmediyye ve Vasiyetnâme'sidir. Vasiyetnâme, Risâle-i Birgivî adıyla da bilinir. Her ne kadar siyaset ve makam düşkünlüğ̈̈; gösteriş ve mansıp hevesi; şöhret ve para hırsı gibi konulara hemen her eserinde temas edip bunların ahlaka aykırı tavırlar olduğuna vurgu yapsa da bu husustaki temel eseri Zühru'l-mülûk isimli risalesidir ${ }^{41}$.

Birigvî'nin yazmış olduğu bir mektup onun siyasetle arasına koyduğu mesafe ve onun bu konudaki tavrına güzel bir örnektir. Mektup, Kanuni'nin kendisinin ve annesinin Ravza-i Mutahhara'ya vakfettikleri kıymetli eşya hakkındadır. Ebussuûd'a sultanınve validesinin vakfını uygun ve caiz görmüştür. Birgivî ise buna katılmamaktadır. Hatta mektup bu sebeple, Reddü'l-Birgivî li-fetvâ Ebussû̂d olarak da bilinmektedir. Ahmet Turan Arslan mektubun kime yazıldığına dair bir kayda rastlamadığını bununla birlikte hocası Atâullah Efendi'ye yazmış olabileceği kanaatinde olduğunu kaydeder ${ }^{42}$. Birgivî'nin soru cevap şeklindeki izahı şu şekildedir:

Soru: Ve merhum-ı merkûnun hill-i sthhatlerinde "Nezr-i Türbe-i Münevvere-i Falır-i Mevcudat Muhammed Mustafa-Aleyhi's-Selam!- deyü Ravza-i Şeri'fe'ye bir murassa' kılıç göndermişlerdir ve validei kerimeleri merhume dahi hal-i sihhatlerinde nezr deyü Ravza-i Mutahhara'ya bir altun zenzirlü altun kındîl gönderüp Hucre-i Şerife'ye ta'li'k etmişler; ve bir altun murassa' kilıç ve bir altun murassa' tac ve bir altun murassa' meftûl ve sekiz evrak la'l ile otuz yedi incü ile bir büyük boyun la'li' ve bir çift la'li' küpe ve yetmiş dört iri boyun incüsü ve dört yüz dirhem bir altun murassa' kemer göndermişler, Medine-i Münevvere'de olan hazinede mahffiz etmişler. Bunlar nice olmak gerekdür; şer'an ne ma'kule nesneye sarf olmak gerekdür? Beyan huyurulup müsab oluna!

el-Cevab: Ravza-i Münevvere'nin masarif-i lâzımesine sarf olunmak lazımdır. Zikr olunan fetvalar bu fakir anladuğum üzere sehv ü hatadur. Bir nice vechile: Amma evvelkisi Bab-ı Salis'de zikr itdik ki, padişahın hazi'nesinde olan ya Beytülmal yahud haramdır. Ĕger bu vasiyyet itdüği şeyleri gendüler satun aldı ise mülkleri olur. Velakin semenini Beytü'l-mal'den viricek Beytü'l-mal'e medyun olur. Bundan gayri

\footnotetext{
36 Osmanlı para vakıflarıyla ilgili ayrıca bkz. Tahsin Özcan, Osmanlı Para Vakıfları: Kanunî Dönemi Üsküdar Örneği, (Ankara: Türk tarih Kurumu Basımevi, 2003); Kaşif Hamdi Okur, "Para Vakıfları Bağlamında Örfün Kaynak Değerine Illişkin Birigvî ve Ebussuûd Arasındaki Tartışmalar", Balıkesirli Bir İslam Alimi Imam Birgivî, Ed. Mehmet Bayyiğit vd. (Balıkesir: 2021), I, 65-75; Osman Cengiz, 16. Yüzyıl Osmanlı Düşüncesinin Kaynakları: Çivizade, Ebussuûd, Birigivî, (İstanbul: Ketebe Yayınları, 2019).

37 Birgivî, "Hâşiye fî Redd-i Akvâli Ebi's-suûd", 249 vd.

38 Emrullah Yüksel, "Birgivî" TDV İslam Ansiklopedisi, VI (Istanbul: TDV, 2010),192; Marinos Sariyannis, Ottoman Political Thought up to The Tanzimat: A Concise History, 63-64.

${ }^{39}$ Huriye Martı, Birgivî Mehmed Efendi, s. 32.

${ }^{40}$ Atâî, Zeyl-i Şekâyık, 179-180; Emrullah Yüksel, "Birgivî" TDV İslam Ansiklopedisi, VI, 192; Mehmet Ali Ünal, "Birgivî Mehmed Efendi ve Osmanlı Fikir Hayatına Etkileri” Uluslararası Balıkesir’e Değer Katan Şahsiyetler Sempozyumu, haz., Şenol Çelik, Serdar Genç, (78 Kasım 2013 Balıkesir), Bildiriler, s. 237.

${ }^{41}$ Huriye Martı-Ahmet Ürkmez, "XVI. Asır Osmanlısında Bir Âlimin Kaleminden Siyaset Eleştirisi: Birgivî ve Zühru'I-Mülûk Adlı Eserinin Tercümesi", neşr., ÇüifD, cilt: 15, sy. 2, 2015, 1-28.

42 Ahmet Turan Arslan, “imam Birgivî’nin (929-9818/1523-1573) Bir Mektubu”, ilmî Araştırmalar, Sayı 5, 1997, s. 61.
} 
neçe na-meşru yerlere sarf itmekle dahi zıman lazım olur. Ve hazineye gelen haramı dahi zımandır. Ve bi'lcümle medyûn-ı müstağrakdır. Vasiyyet, ba'de'd-deyndür. Medyûn-ı müstağrak olanın vasiyyeti caiz değildir. $" 43$.

Daha sonra muhtelif fikıh kitaplarından nakiller yapan Birgivî konuyu geniş biçimde açıklamaktadır. Onun beytü'l-mal ve idare konusundaki hassasiyeti bu mektupta açıkça ortaya çıkmaktadır. Birgivî bürokrat bir alim değildi. Bununla birlikte Sokullu Mehmed Paşa'ya yaptığı tavsiyelerde olduğu gibi siyasetten tamamen bağımsız ve ona ilgisiz de kalmadı. Esasında bürokrat alim tipi klasik dönemde kendi karakterini oluşturmuştur. Esasen onun muhatabına da bazı hususi tavsiyeleri vardır:

"Ve dahi sizlerin kuzat ve ümera umuruna tasaddi itdüğünüzden bu fakir hiç faide anlamaz; eğer dünyevî ve eğer uhrevi. Belki iki cihetden zarar vardır anlaruz. Vezirin size ineinmesi bu hususdan. Zira anlar bu hususda müstakil olmak isterler. Siz anda mani' olursiz; nice murad itdüğ̈̈ hilaf olur. Andan 'adavet naşi olur. Ĕger uhra hali dersenüz, kuzatın ve ümeranın hali ma'lumunuz ise bunlara mu'avenetin zararında şübhe itmezsiz. Kütahiyye'de bu fakire demişdiniz ki, "Bu kadar kanşmamız padişah oluncadır; kendi ile de böyle söyleşmişizdir. Ol zamanda el çeküp kendi halimize meşgul oluruz." Amma şimdi ol va'deye vefa olmadi. İmdi, sizden mercu olan oldur ki, cümleden el çeküp kapunuzu bekidüp gelenlere "Biz sahib-i emir degilüz"; begler, sipahller ise, anlar içün vezir nasb olunmuşdur; kuzat ve müderrisin ise, anlar içün Kadîaskerler vaz' olunmuşdur; havadis istiftast içün Müftl vaz' olunmuşdur. Bizim bunlardan biri vazifemiz değildür, deyü redd idesüz. Padişah hazretine da'vet olundukda varup düşdüğüne göre ba'zı emr-i ma 'ruf ve nehy-i münker söylemek üzere kasr idesüz. Kendi nefsünüz ıslahına meşgul olub baklyye-i ömrü nefsi halvet ve taatda geçüresiz. Dünyaya bir dahi gelmesiz ki, ta o vakit tezevvüd idesiz. Ehlin ve 'ıyalin dünyası $i$ çü n dininizi ylkmayasuz, ecuebiler kanda kaldı! Bu nasihati kabul i dersenüz di ninizi olduğundan ma 'ada dünyanız dahi ma 'mur olur. Vezir dahi muhabbet ider. Zira şirketden kurtuluş, istiklal biisll olur. Bu aralı̆̆a karışmamağla beşayiş kurtulurmuşsınız bari. Heyhat, heyhat! ${ }^{44}$

Onun bu nasihatleri makam ve mansıp konsundaki ve idarecilerle olan muamelesindeki net tavrını ortaya koymaktadır. Birgivî’nin padişah vakıflarıyla ilgili bir başka fetvası ise şöyledir:

Mes'ele (47): “An Aliyyin radiya'llahü anh: İnne li külli kâriin fì külli senetin mietey dînârin ve elfe dirhemin min beyti'l-mâli ve in ehazehâ fi'd-dünyâ ve illâ ehazehâ fi'l-âhireti ve kâne Aliyyün yu 'tî hamelete'l Kur'ani'l- Azîmi hazzahû min beyti'l-mâli" ${ }^{45}$ Pes, bu rivâyete mağrûr olub cum 'a günü devrhânlara vakf olan evkâf-ı selâtînden okudukları Kur'an-ı Azîm mukâbelesinde virdikleri akçeyi alub ekl itmek câiz midir? Ammâ niyet bu olsa ki "padişah vakfıdır, beytülmale yakındır ben de mahalli müstehakkım" dise yahut ne mikdar okunacağı tayin olunup emr olunmuş değildir heman hazırînin istimâl içündür ücret değildir, sıladır diseler bu asıl za 'mın nef 'i olup şer 'a muvâfik olur mı? Ale 't-tafsîl bu ukdeyi hall buyurub müsâb olalar.

el-Cevâb: Bu mes'ele cevabı bast ve tafsîle muhtacdır. Zamanımız hâkimleri müsaade etmez velâkin icmâli budur ki padişahların vakıfları ekser köyler ve yerlerdir. Anlar ise padişahların mülkü değildir, heman mütevellîler gibidir. Vaklf-ı mülkî, meşrudur. Tutalım mülk de olsa yerlerden öşr ve resm-i zemîn adına alınanlar haraç hükmündedir. Öşrün ve haracın vakfi sahih değildir. Zira şer', anlar içün mesârif ta 'yin itmişdir. Vâkıf ânı tağyîre kâdir değildir ve Müslümanlardan bennâk91 deyu ve yerlerden tapu deyu aldıkları haracın masârifi menfaât-ı âmmesi olandır. Mücerred fakir değildir. Mukâtil ve ulemâ ve kudât

\footnotetext{
${ }^{43}$ Arslan, Agm, s.64.

${ }^{44}$ Arslan, Agm, s.72.

${ }^{45} \mathrm{~Hz}$. Ali'den şöyle rivayet edilmiştir: Her sene, her Kur'an okuyucusuna beytülmalden iki yüz dinar ve bin dirhem ödenirdi. Onu bu dünyada alırsa o onundur. Almazsa sevabını ahirette alır. Hz. Ali Kur’an-ı Azîm’i taşıyanlara (hafızlara) Beytülmalden paylarını veriyordu".
} 
ve vu'âz ve müftîn müteallimîn ve muallimîn gibi, eğer devr-hânlardan bunlardan biri ise yerlerden alinan eğer öşür eğer resm-i zemîn kadar kifâyet helâl olur. Amma bennâk ve ânın emsâli herkese haramdır. "46.

Birgivî Mehmed Efendi, Kanûnî döneminde hocası Abdurrahman Efendi'nin Rumeli Kazaskerliğini birinci defa yürüttüğü 1551-1557 yılları arasında onun vasıtasıyla Edirne kassâm-1 askerîsi oldu ve bu görevini dört yıl boyunca sürdürdü. Bu arada muhtelif mekânlarda ders okutmaya, vaaz ve irşada devam etti $^{47}$. Onun kassâm-ı askerî iken aldığı maaşını sonradan dağıttığı nakledilir. Memurlukta yükselme imkânı varken sade bir hayatı tercih ettiğini söylemek mümkündür. Zira doğru olan bir hükmü hakşinas biçimde söylemesi ve haksızlığa yaptığı itirazlar onun tabiatının devlet kademelerine çok uygun olmadığını gösterir niteliktedir. Bununla birlikte Birgivî'nin memurluk ve müderrislik tecrübesi son eseri denebilecek olan Tarîka'da farklı biçimlerde yansır. Birgili Mehmed Efendi Tarîka'nın başında bir hadis paylaşır: "Sizden Allah Teâla'dan korkmanızı, Habeşli bir köle olsa bile başınızdaki yöneticilerin emirlerine kulak vermenizi ve onlara itaat etmenizi tavsiye ediyorum. Sizden hayatta kalanlar olursa ileride birçok ihtilaf görecektir" 48 . Buna göre onun dünyasında devlete ve yöneticiye karş1 çıkmama veya mevcut bir isyana destek vermeme, toplumdaki huzur ortamının devamı ve kaosun oluşmaması için çok önemliydi. Nitekim "fitne" kavramını açıklarken imamın namazı uzatması, insanlara zulüm yanında devlet başkanına karşı isyan çıkarmayı da saymıştır ${ }^{49}$. Birgivî İmamın/devlet başkanının nasıl bir usulle başa geçeceği konusuna değinmese de zamanının en faziletlisi olarak bilinmesinin gerekli olmadığını ifade etmektedir. Keza devlet başkanının günahkâr olmasından veya zulmünden dolayı azledilemeyeceğini vurgulamaktadır ${ }^{50}$.

Ona göre tâbi olan (başkasını taklit eden veya peşinden giden) kimsenin tâbi olduğu kimseye itiraz ve muhalefet etmemesi gerektiği gibi itaatsizlik etmesi de hatalı bir davranıştır. Reayanın, emir ve kadıya; çocuğun babasına; kölenin efendisine; talebenin hocasına; kadının kocasına ve cahilin de âlime muhalefet etmesi dilin afetlerindendir ${ }^{51}$. Onun afet teorisi, çerçeve metin olan Tarîka'nın tamamına dağılmış biçimde göze çarpar ${ }^{52}$. Toplum yaşamında ortaya çıkan pek çok bozukluk ve fesadın kaynağı Birgivî'ye göre, dinden ve onun ahlakî emirlerinden uzaklaşmadır ${ }^{53}$. Ona göre "itaat" demek her şeye boyun eğmek manasına gelmemektedir. Bir bilginin kemalini ve değerini tasvir ederken, idareciden çekinmeksizin karşısında onun hoşlanmayacağı bir şey de olsa hakikati ifade edebilen, kendi menfaatini dikkate alarak doğruları çarpıtmayan, sultan ile düşmanı arasında bile hakka hakikate riayetle hüküm verip, yöneticiden tarafa meylederek karar vermeyen bir şahsiyet portresi ortaya koyan Birgivî, sultan ile halk yahut da zengin ile fakirin bir âlim için insanlık onuru bakımından eşit olduğunu, zengine zenginliği sebebiyle, makam sahibine de makamından dolayı "tevazu” göstermeyip, bilakis alçak gönüllüğü ancak Allah Teâlâ'nın rızası için göstermek gerektiğini vurgular ve şöyle der:

\footnotetext{
46 Mehmet Özkan, “Osmanlıca Metinlerde İslam Hukuku Motifleri: Fetâvâ-yı Birigivî Örneği”, Balıkesir Üniversitesi Illahiyat Fakültesi Dergisi Journal of Balikesir University Faculty of Theology, Cilt 1, Sayı 1, Hazran 2015, (ss.79-107), 95.

${ }^{47}$ Bursalı Mehmet Tahir, Osmanlı Müellifleri, I, 284; Atâî, Zeyl-i Şekâyık, s. 180; Martı, Birgivî Mehmed Efendi, 35; Emrullah Yüksel, "Birgivî" DiA, 6/192; Katharina Anna Ivanyi, Virtue, Piety and the Law: A Study of Birgivī Mehmed Efendī's al-Taríqa alMuhammadiyya, A Dissertation Presented to the Faculty of Princeton University in Candidacy for the Degree of Doctor of Philosophy, November 2012, 124. Mehmet Özkan, XVI. Yüzyıl Osmanlı Alim ve Fakihi Muhammed Birgivînnin Fıkhî Meselelere Yaklaşımı, (Bursa: Emin yayınları, 2016), s. 47.

48 Ebu Davud, Sünnet, 5; İbn Mace, Cihad 39; Birgivî, Tarîka, (Taha), s. 26.

${ }^{49}$ Birgivi, Tarîka (Taha), s. 292.

50 Yüksel, Mehmed Birgivî́nin Dinî ve Siyasî Görüşleri, s. 136.

51 Birgivi, Tarîka (Taha) s. 390; Birgivî, Tarîka, (Nedvî), s. 421. Krş. Kâfiyecî, Kitâbü't-taysîr fî kavâidi ilmi't-tefsîr, terc. İsmail Cerrahoğlu, (Ankara: Ankara Üniversitesi illahiyat Fakültesi Yayınları), s. 86.

52 Birgivî, Tarîka'da kalbin, dilin, kulağın, gözün, elin, midenin, tenasül uzvunun, ayağın afetlerini saydığı gibi bir organa özel olmaksızın bedenin afetlerini de ilave eder. Birgivi, Tarika (Taha) s. 110, 311, 413, 416, 429, 437, 447, 478.

53 Selim Hilmi Özkan, "Bir Muhalefet Olarak İmam Birgivî" Uluslararası Balıkesire Değer Katan Şahsiyetler Sempozyumu (7-8 Kasım 2013- Balıkesir) Ed. Şenol Çelik, Serdar Genç, (Balıkesir: 2014), (381-387), s. 384.
} 
"Âlim, idarecilerle sıkı fikı olmaktan sakınan, onların dünyasından uzak duran, vakıf malı almaktan çekinen, Allah'ın kendi kısmetine takdir ettiği kadarına kanaat gösterip, daha fazlasını istemeyerek mal toplama hevesinde olmayan ve insanlarin elindeki nimetlere tamah etmeyen kişidir." 54 .

Ona göre zaruret olmaksızın kendi zamanındaki emir ve kadıların huzuruna çıkmak da ayağın afetlerindendir ${ }^{55}$. Bazı kadıların aldıkları rüşvet veya memurluğun hakkını vermemelerinden kaynaklanan maaşın helallik şüphesi onu bu tavra zorlamaktaydı. Devlet memuriyetine sıcak bakmayan Birgivî devletle asgarî ilişkiyi tavsiye etmektedir. Bunun nedeni siyaset ile ilmi tam olarak bağdaştıramaması, siyaset ve idare sahasında gördüğü haksızlıklar olmalıdır. Onun bu olumsuz tavrı aslında sadece idareye değildir. Medrese yoluyla memuriyete açılan kapıya da aynı şekilde tepkilidir:

Ve dahı ebnâma vasiyyetüm oldur ki danişmend olup medreseye varmayalar, kadıasker kapusina mülâzemet itmeyeler ve kadı ve beğ kapusına ihtiyarlariyle varmayalar Allah teâlâya tevekkül ideler, ilm-i nâfi tahsîline ve neşrine ve a'mâl-i sâliha ve takvaya meşgul olalar, helâlden sûk olınandan kaçmayalar, kimseden mâl ve nimet mansıb taleb itmeyeler "Ve men yettekıllâhe yec'al lehü mahrecen ve yerzukhü min haysü lâ yahtesib ve men yetevekkel ale'llâhi fe-hüve hasbüh" ayetin daim tahammül ile okiyalar ${ }^{56}$.

İdarecilik ve hâkimlik istemek ona göre dünya malı dilenmek gibidir. Dilencilik ise sağlığı ve günlük iaşesi olan kimse için caiz değildir. Tarîka' daki nakle bakılırsa bazı âlimler kadılık görevini isteyerek kabul etmenin caiz olmadığını söylemişler ve tercih olunan görüşe göre ise bu görevi geçmek, istemeden veya araya birini sokmadan olursa ruhsaten caizdir. Buradaki ruhsat ifadesi usul-i fikıtaki bir ilkeyi hatırlatmaktadır ${ }^{57}$. Birgivî’nin niçin sonradan memuriyeti bıraktığı ve herhangi bir görev kabul etmediği bu tavırdan anlaşılmaktadır. Zira bir hâmî ve koruyucu edinmeden böyle bir vazife almak mümkün değildi. Birgili Mehmed Efendi'nin Ataullah'a siyasete karışmama, kadılar ve ehl-i örf ile rekabete girmeme tavsiyesi onun ilim-siyaset ilişkisine dair kanaatini göstermektedir. Ona göre böyle bir tavır, ilmin vakarına yakışmadığı gibi vezirlerin işine karışmak olacağından düşmanlığa sebep olacaktır. Dolayısıyla böyle bir tavır hem dünya hem ahiret açısından bir kayıtır ${ }^{58}$. Onun Birgi'deki ehl-i örf ile münasebeti hakk1 söylemekten çekinmeyen tarzdadır. Birgivî, Atâullah Efendi’ye yazdığı bir mektubunda Birgi Beyi ile görüşmesini şöyle anlatır:

Birkaç kâfir Müslüman olmuş, pes donanma ideriz deyû her tarafdan âlet-i harb ü lehv ile kimesneler cem' oldılar. Ma 'lûm-ı şerîfdir ki bu makūle nesne âdeten fesâddan hâlî olmaz. Ve dahî celeb tâifesi âlet-i lehv ile bâzârda gezüb kimini dögüb ve kiminün esvâbını gasb idüb çokca fesâd eylediler. Bu fakîr bir çâvuşı çağırub 'Paşaya var. Bazı kelâmımız var. Ânlara söylemek isteriz izin verirler ise varalum' deyû

54 Birgivî, Zühru'l-mülûk, s. 7.

55 Birgivi, Tarîka (Taha) s. 443.

56 “...Her kim de Allah’tan korkarsa Allah ona bir çıkış yolu gösterir. Onu, hiç ummadığı bir yerden rızıklandırır. Her kim Allah’a tevekkül ederse, Allah ona yeter..." Talak Suresi 65/2-3.

57 Ruhsat, Bazı mazeretlerden dolayı aslî hükmün gereğine uymamayı meşrû hale getiren geçici hüküm olarak tanımlanmaktadır.

58 “...ve dahî sizlerin kuzât ve umerâ umuruna tesaddî itdüğünüzden bu fakir hiç fâide anlamaz. Eğer dünyevî eğer uhrevî belki iki cihetten zarar var anlarız. Vezîrin sizi incitmesi bu husustan. Zira anlar bu hususta müstakil olmak isterler. Siz anda mâni olursız. Nice murâd etdüği hilâf olur. Andan adavet nâşî olur. Eğer uhrâ hali dirsenüz kuzâtın ve umerânın hali eğer malumunız ise bunlara muâvenetin zararında şüphe etmezsiz. Kütâhiyye'de bu fakîre dimişdiniz ki bu kadar karışmamız padişah oluncadır. Kendi ile de söyleşmişizdir. Ol zamanda el çeküb kendi halimize meşgûl oluruz. Ammâ şimdi ol va'deye vefâ olmadı. İmdi sizden mercû olan oldur ki cümleden el çeküb kapunız bekidüb gelenlere: Biz sahibi emr değilüz! Beğler sipâhiler ise anlar içün vezîr nasb olunmuşdır. Havâdis istiftâsı içün kâdıaskerler vaz' olunmuşdır. Bizim bunlardan biri vazîfemiz değildür, deyû redd idesiz. Padişâh hazretine da'vet olundukda varub düştüğünüze göre, bazı emr-i ma'rûf ve nehy-i münker söylemek üzere kasr idesiz. Bu nasîhatı kabul iderseniz dininiz ma'mûr olduğundan mâadâ dünyanız dahi ma'mûr olur. Vezir dahi muhabbet ider. Zira şirketten kurtulur, istiklâl hasil olur" Birgivî, Mektup, 230'dan naklen Hulusi Lekesiz, “XVI. Yüzyıl Osmanlı Düzenindeki Değişimin Tasfiyeci (Püritanist) Bir Eleştirisi: Birgivî Mehmet Efendi ve Fikirleri", Doktora Tezi, Hacettepe Üniversitesi, 1997, s. 157. 
gönderdim. 'N'ola gelsün' dimişler. Varub bu fesâdları beyân itdik. Didiler kim 'donanma men'ine kâdir değiliz. Ammâ âlet-i lehvi men' idelim, cüz'îdir' deyüb hemân çâvuşlara ısmarladı. 'Her kimin elinde âleti lehv görürsenüz fadın. Ânlar dahî bir ikisini fadmışlar. Hemân sebeb bu olmuş. Paşa sözünü tenfîze kâdir değil. Ancak zulüm def' eylemek şânindan değil ${ }^{59}$.

Sokullu Mehmed Paşa'ya dahi nasihatte de bulunan Birgivî'nin, ilmin ve âlim izzetini muhafazada çok hassas olduğu anlaşılmaktadır ${ }^{60}$. Birgivî'nin düşünce dünyasının merkezinde emir bi'l-maruf nehiy ani'lmünker yer almaktadır. Onun sultan da dâhil olmak üzere devlet erkânını ikazdan çekinmediği anlaşılmaktadır. İkazları hukuksuzluğun ve adaletsizliğin, ahlâka ve dine aykırı uygulamaların sona erdirilmesine yöneliktir. Hutbe esnasında sultanın ismi anıldığında zamanının müezzinlerinin sultanlar için söyledikleri övgü sözlerinin hatta Allah razı olsun demelerinin, onlara sesli dua etmelerinin çirkin işlerden oğlunu söyleyen Birgivî, bunu yaparken şüphesiz ki geçmişinden aldığg cüret ve güçle konuşmaktayd1 ${ }^{61}$.

XVII. asır Osmanlı siyaset hayatı içinde güçlü bir grup olan Kadızâdelilerin, Birgivî ile meşruiyet kazanma teşebbüsleri de dikkat çekmektedir ${ }^{62}$. Bilindiği gibi Kadızâdeliler hareketi Kadızâde Mehmed Efendi (ö. 1635) ile başlamıştı. Kâtip Çelebi, Kadızâde Mehmed'in İhyâ, Şerh-i Mevâkıf, Dürer ve Tarîkat$i$ Muhammediyye okuttuğu derslerine katılmış ${ }^{63}$ ve derslerinin çoğunun sathice ve basit olduğunu söylemiştir. Kadizâde'nin Murad Paşa camiinde Câmi' ve Muhtasar ve Sadru'ş-şerîa dersleri epeyce devam etmiş ve bu uzun müddet sayesinde güzel konuşması (hüsn-i ta'bîr) ve canayakın ders anlatması (lütf-i takrîr) ile tanınmıştır ${ }^{64}$. Hareket, sonraları Üstüvânî Mehmed Efendi (ö. 1661) ve Vânî Mehmed Efendi (ö. 1685) ile devam etmiştir. Kadızâdeliler IV Murad, Sultan İbrahim ve IV. Mehmed dönemlerinde siyaset üzerinde hissedilir bir etki oluşturmuşlardır. Kadızâde Mehmed ile Abdülmecid Sivâsî (ö. 1049/1639) arasındaki tartışmalar Fakılar ile Sofular mücadelesi olarak bilinmektedir ${ }^{65}$. IV. Murad'ın esasen, hakimiyeti eline alabilmek için toplumda belirli bir ağırlığı ve karşılığı olan kimselere ihtiyacı olduğu açıktı. Bu sebeple hem Kadızâde'ye hem de Sivasî'ye iltifat ederek yakınlık göstermiştir ${ }^{66}$. Yukarıda geçtiği gibi Kadızadeliler için Birgivî bir meşruiyet aracı idi. Zira Kadızadelilerin gündeme aldığı konular ile Birgivî'nin gündemi büyük oranda farklıdır. Nitekim gerek Katip Çelebi gerekse Naîmâ, Kadızadelilerin gündeme getirdiği münakaşa mevzuları arasında Birgivî’nin çok büyük önem verdiği vasiyyetsiz para

\footnotetext{
59 Birgivî, Zühru'l-mülûk, s. 8.

60"Kalbin afetlerinin on üçüncüsü dalkavukluk ve tevazuda aşırıya kaçmaktır. Mesela bir âlimin yanına bir ayakkabı tamircisi geldiğinde yerinden kalkıp onu oturtması sonra onun önüne geçip ayakkabılarını düzeltmesi ve onun evinin kapısına kadar onu uğurlaması zillettir" Birgivi, Tarîka (Taha) s. 168.

${ }^{61}$ Birgivi, Tarîka (Taha) 374. Keza bu ahlakçı muhaddis, idarecilerin aldıkları hediyelerden devletin giderlerine, beytülmali oluşturan kaynaklardan halka ait vergilere, idarecinin adil davranmasından zulmün ahiretteki bedeline kadar imanî, ahlâkî, malî ve sosyal pek çok konuda ikazlarda bulunmuştur. Birgivî, Zühru'l-mülûk, s. 23.

62 Kadızâdelilerin Birgivî’yi sadece bir meşruiyet aracı olarak kullandıklarına dair bkz. Cengiz, 16. Yüzyıl Osmanlı Düşüncesinin Kaynakları, 247 vd.

63 Kâtip Çelebi, Mîzânül-Hakk, 137-138, 230.

64 Fezleke-i Kâtib Çelebi, (İstanbul: Cerîde-i Havâdis Matbaası, 1287), II, 182.

65 Ferhat Koca, "Osmanlı Dönemi Fıkıh-Tasavvuf İlişkisi: Fakılar ile Sofular Mücadelesinin Tarihi Serüveni” Hitit Üniversitesi Ilahiyat Fakültesi Dergisi, v1 n1 (20020630): 73-131; Mehmet Özkan “Osmanlı’da IIlmihal Geleneği: Kadızâde Mehmed Efendi (1045/1635) ve "Risâle-i Kadızâde” Adlı Çalışması" İslam Hukuku Araştırmaları Dergisi, Sayı: 27 Nisan 2016, 561.

${ }^{66}$ Krş. Marinos Sariyannis, Ottoman Political Thought up to The Tanzimat: A Concise History, (Boston: Brill, 2019), 104-105; Ahmet Ürkmez, Kadızadeliler-Sivasiler Tartışmalarının Hadis IImine Etkisi ve Idrâkü'l-Hakîka Örneği, (Yüksek Lisans Tezi: Konya, 2000), 225. Nitekim Zekeriyazade Yahya'ya (ö.1053/1644) gösterdiği muhabbet ve onu şeyhülislam yapması buna işaret etmelidir. Sultan IV. Murad'dan aldığı ihsanı dervişlere ve halka harcamayıp yolsuzluk yaptığı için idamına hükmedilip şeyhülislamın şefaatiyle cezası İstanbul'a sürgüne çevrilen Mevleviliğin Konya Postnişini Ebubekir Çelebi (ö.1048/1638) gibi farklı örneklere de rastlanır. Şeyhülislam Zekeriyyazade Yahya'nın Mescidde riyâpîşeler etsin ko riyâyı / Meyhaneye gel kim ne riyâ var ne mürâyi beyti meşhurdur. Naîma, Tarih, V, 55.
} 
vakfının caiz olmamasına yer vermemişlerdir ${ }^{67}$. Kadızâdeliler tartışmasında vâizlerden ve sûfîlerden öne çıkanları şöyle sıralamak mümkündür: a) Kadızâde Mehmed Efendi (öl.1045/1635) - Abdülmecîd-i Sivâsî Efendi (öl. 1049/1639) b) Üstüvânî Mehmed Efendi (öl.1072/1661) - Abdülehad Nûrî Efendi(1061/1651) c) Vânî Mehmed Efendi (öl. 1096/1685) - Niyazî-i Mısrî (öl 1105/1694) ${ }^{68}$. Kadızâdeliler hareketini benzer hareketlerden ayıran bazı temel unsurlar göze çarpar. Bunlar, Kadızâdeliler' in bilinçli biçimde kullandıkları yöntemler ve içinde bulundukları şartlar ile ilgilidir ${ }^{69}$ : Taraftar toplamak-örgütlemek, kamusal destek aramak-kullanmak, şiddet ve tedhişe başvurmak ve mevcut sosyal ve ekonomik sıkınt ${ }^{70}$.

Bazı tarîkatlar, sonraki asırlarda Birgivî ve eserleri üzerine yoğunlaşarak onun etki sahasını genişletmişlerdir. Bunun iki mühim sebebi olmalıdır:

a) Her grubun görmek istediği kendi "Birgivî imajını" inşa etme ve Birgili Mehmed Efendi' yi sahiplenme arzusu

b) Sufîlerin ve özellikle de vahdet-i vücud felsefesini benimsemiş olanların, kendilerine yönelik "dışlama ve ötekileştirme" baskısını gögüsleme; kendilerinin zındık veya mülhid olmadıklarını ve "Ehl-i sünnet" kimliğini paylaştıklarını gösterme arzusu ${ }^{71}$. Bu sebepler dolayısıyla kurumsal manada tasavvuf taraftarlarının özellikle vahdet-i vücudcuların ya da İbnü'l-Arabî muhiplerinin de Tarîka'yı şerh ettiklerini görüyoruz $^{72}$. Tarîka ile Ehl-i Sünnet kimliğini pekiştiren şârihler aynı zamanda da bu esere kendi meşreplerine göre bir yorum ilave etmiş oluyorlardı. Şerhlerin, hangi metinlerin daha fazla tercih edilip okunacağını tayin ettiği yönündeki kanaat esasen bu vadide de geçerlidir. Bununla birlikte şerhler metni dönüştürme ve algıyı yönetme hatta müellifin muradını açıklama iddiası sebebiyle onu pek çok kapalı meselede konuşturma anlamına geldiği için, gerçekten de mühim bir rol üstlenmiş olmaktadır.

\section{Birgivî’nin İlim Dallarına Bakışı ve İtirazları}

XVI. asır Osmanlı bilim ve düşünce dünyası bakımından en verimli zaman dilimlerinden biridir. Bilindiği gibi İstanbul, XV. Asrın ikinci yarısından sonra Kahire ve Tebriz gibi şehirlere düşünce üretmek bakımından alternatif hale gelmişti. Osmanlıların ilk devirlerinde öğrenciler ilim tahsili için daha çok Anadolu dışına özellikle de Mısır, Şam ve Maveraünnehir bölgelerine giderken XV. Asrın sonlarında İstanbul ilmî kimliğini ispatlamıştı. XV ile XVI asır arasındaki en büyük fark ise Şiî Safevî tehdidi ile ortaya çıkan siyaset güdümündeki mezhebî çatışma oldu. Bu nedenle özellikle fikıh alanında Hanefî mezhebi Kanunî'nin fermanı ve Şeyhülislam Ebussuûd 'un fetvasıyla hakimiyet alanını geniş̧letmiş ve

67 Kâtip Çelebi, Mîzânüll-Hakk, 137-139; Naîmâ, Tarih, VI, 219-220.

68 Ibrahim Baz, Abdülehad Nûrî-i Sivâsînin Hayatı, Eserleri ve Tasavvufî Görüşleri, Doktora Tezi, (Ankara: 2004), 51; Koca, "Osmanlılar Dönemi Fıkıh - Tasavvuf iliş̧kisi: Fakılar ile Sofular Mücadelesinin Tarihi Serüveni”, 108-113.

${ }^{69} \mathrm{Krş}$. Baz, Abdülehad Nûrîi-i Sivâsî́nin Hayatı, Eserleri ve Tasavvufî Görüşleri, 57-59.

70 İktisadî refah ve kamusal güvenlik ile toplumsal hoşgörü arasında doğru orantı bulunduğu kaydedilmelidir. Kısaca bir toplumun refah seviyesi arttıkça o toplumda kendine benzemeyene karşı hoşgörünün de artması söz konusudur. Akis durumda ise zaten var olan sosyo-ekonomik sıkıntılar öteki üzerine fatura edilmekte ve bir yansıtma yapılmaktadır.

71 Mesela Nûreddin Cerrâhî, Cerrâhiyye yolunun Ehl-i sünnet itikadına tavizsiz bağıılı̆̆ını Birgivî’nin Vasiyetnâme'sini okuyup okutmak suretiyle göstermiştir. Bkz. Şenay Yola "Cerrâhiye" TDV İslam Ansiklopedisi, VII, 418.

72 Nablusî’nin ve Hâdimî’nin şerhleri bu bakımdan son derece önemlidir. Nablusî, tam bir vahdet-i vücudcu olduğu gibi Hâdimî de Muhyiddin İbnü'l-Arabî gibi mutasavvıfların zâhirî anlamda küfrü gerektiren sözlerinin ihtiyatla karşılanıp küfürlerine dair fetva verilmemesinin daha uygun olacağı kanaatindeydi (Mustafa Yayla "Hâdimî, Ebû saîd" TDV İslam Ansiklopedisi, XV, 25). Bu konuda Şimşek'in görüşü şöyledir: "Nakşî-Müceddidî bir Sûfî olarak Hâdimî’nin vahdet-i vücûd hakkındaki görüşleri oldukça dikkat çekicidir. İbnü’l-Arabî ve vahdet-i vücûd karşıtlarınının tutarsızlarına işâret ederek eleştirilerdeki ölçüsüzlüğün sonuçlarının dikkatle değerlendirilmesi gerektiğini belirtir." Halil ỉbrahim Şimşek, "Anadolu Müceddidîlerine İlişkin Bazı Tarihî Bilgilerin Kullanılışı Üzerine Bir Değerlendirme", Gazi Üniversitesi Çorum ilahiyat Fakültesi Dergisi I/2, 2002/2, 222. 
tahkim etmişti. Bu çerçevede Birgivî'nin tavrı ise daha sert ve kuralcı bir hal almıştı. Zira kendisine şeriatı müdafaa vazifesi yüklemişti. Bu nedenle Birgivî için ilmihal öğrenmek farzd1 ${ }^{73}$.

Kâtip Çelebi, onu dinî ilimler konusunda inceliklere hakim ve araştırmacı biri olarak tanıtır ve mantık ilmine hakimiyetini över. Bununla birlikte felsefî ve aklî ilimlerin onun meşrebine uygun olmadığını kaydeder. Hatta "halkın örf ve ahvaline vakıf olmak için tarih de okumamış" bir kimsedir" ${ }^{74}$ Ona göre bilgiye konu olan şey, farz veya haram ise onu öğrenmek farzd1. Vacip veya mekruh ise vacip; sünnet ise sünnet; nafile ise, o konudaki bilgi de nafile idi ${ }^{75}$. Bu konuda onun metodolojik bir tavır takındığ 1 söylenebilir. Zaten çerçeve bir metin olan Tarîka da var olan ahlak felsefesi son derece sistematik işlenmiştir. Bu çalışmasında onun Gazzalî’den ilham aldığı açıktır. Aslına bakılırsa ilimlerin tasnifi ve değerlendirilmesinde de Gazzalî’ye yakındır. Birgivî'ye göre fikıh, tefsir, hadis, usül ilimleri, kırâat ve özellikle ferâiz (miras hukuku) için hesap gibi ilimleri öğrenmek farz-1 kifayedir. Herkesin bu konuda çaba harcamasına gerek olmasa da ehil olan kimselerin bu ilimlerle meşgul olmasını ister. Birgivî’ye göre Arapça diğer dillerden üstündür ${ }^{76}$. Zira Kur'an ve Sünnet'in dilidir. Ona göre Kur'an ve Sünnet her bakımdan ölçüt olarak alınmalıdır. İlme büyük değer vermiş olsa da onun zaviyesinden, bazı ilimleri tahsil etmek doğru değildir. Bu arada Birgivî hangi ilimlerin farz veya gerkeli hangilerinin tahsilinin yasak olduğuna temas ederken kaynak vermeyi ihmal etmez. Onun temel müracaat eserleri ise Bezzâziyye, Tatarhâniyye, Hulâsa ve Nevâzil gibi kazuistik fetva çalışmaları olduğu gibi İhyâ, Bostanü'l-Arifîn, Talimü'l-Müteallim gibi ahlak ve eğitim kitapları da yer alır ${ }^{77}$.

Siyaset ve ilim başlığı altında Birgivî'de ele alacağımız temel konu elbette para vakıfları konusunda Ebussuûd ile yaşadığı münakaşadır. Zira para vakfı, Çivizâde'nin teşebbüsleriyle bir süre yasaklanmış olsa da 1548 senesinde bir hükm-i şerîf ile serbest bırakılmıştır ${ }^{78}$. Birgivî, Ebussu'ûd'un para vakfı konusundaki risalesine bir reddiye yazarak bu konuyu tekrar gündeme taşımışt ${ }^{79}$. Birgivî'nin para vakfı uygulamalarına karşı çıkma sebebi kendi ifadesine göre, söz konusu paraların muamele-i şer'iyye ile işletilmesinden çok, bu muameleye riayet edilmeyerek karz ve bey akitleri üzerinden faize düşülmesiydi. Zira mevcut durumda Birgivî'ye göre îne usulü ile işletilmekteydi ${ }^{80}$. Ebussuûd Efendi muâmele-i şer'iyye usulüne uygun yapıldığı takdirde sakınca görmezken Birgivî bu görüşü paylaşmakla birlikte fukahanın sakının îneden, $o$ laîneden sözünü nakleder ${ }^{81}$. Buna göre Birgivî Mehmed Efendi, toplumda şerî muamelenin usulüne uygun yapılmadığı kanaatindedir. Birgivî, Ebussuûd Efendi'ye reddiye olarak yazdığı ve çoğunlukla es-Seyfü'ssarim adıyla bilinen eserinde vasiyetsiz para vakfina ve Ebussuûd'un bu konudaki düşüncelerine itiraz etmiştir. Birgivî risalesinin başında şunları dile getirir:

\footnotetext{
73 Birgivî, Tarîka (Nedvî), 108; Özkan, Muhammed Birgivînnin Fıkhî Meselelere Yaklaşımı, 63.

74 Kâtip Çelebi, Mizânü'l-Hak fi ihtiyâri'l-Ehakk: İslam'da Tenkit ve Tartışma Usulü, Sad. Süleyman Uludağ Mustafa Kara, (İstanbul: Marifet Yayınları, 2001), s. 135.

75 Birgivî, Tarîka (Nedvî), s. 111.

76 Birgivi, Tarika (Taha), s. 69.

77 Birgivi, Tarîka (Taha), s. 68-73. Kazuistik çalışmalar ve nevâzil edebiyatı için bkz. Mustafa Türkan, Hicri Altıncı Asır Hanefí Nevâzil Edebiyatı, Ankara, 2020, s. 113-239.

78 Mehmet Gel, “Kanûnî’nin Para Vakfı Yasağını Kaldıran 1548 Tarihli Hükm-i Şerîfi'nin Yeni Bir Nüshası” Akademik Bakış, Cilt 4 Sayı7 Kış 2010, s. 185-192.

79 Birgivî, "Hâşiye fî Redd-i Akvâli Ebi's-suûd"," Resâilü'l-Birgivî, 249-281. Özcan, Osmanlı Para Vakıfları, 47-50. Marinos Sariyannis (with a chapter by Ekin Tuşalp Atiyas), Ottoman Political Thought up to The Tanzimat: A Concise History, Foundation for Research and Technology-Hellas-Institute for Mediterranean Studies Rethymno, (2015), s. 45.

80 Îne, vadeli satılan bir malın peşin para karşılığında daha düşük bir bedelle geri satın alınmasını ifade eden terim olup en yaygın açıklamaya göre, bir kimsenin bir malı belli bir fiyat karşılığında vadeli olarak satıp aynı malı peşin parayla sattığı fiyattan daha ucuza geri satın almasıdır. Bu şekilde yapılan alım satıma îne denilmesinin sebebi, akde konu edilen malın tekrar satıcıya dönmesi ve müşterinin hemen nakit parayı (ayn) elde etmesidir. H. Yunus Apaydın “T̂ne” TDV İslam Ansiklopedisi, XXII, 283.

81 Birgivî, "İnkâzü'l-Hâlikîn”, 81; Özkan, Muhammed Birgivî’nin Fıkhî Meselelere Yaklaşımı, s. 245-248.
} 
$B u$, vasiyetsiz yahut ölüme bağlanmaksızın para vakfetmenin batıl olduğunu ortaya koymak için yazılmış bir risaledir. Çünkü zamanın müftüsü Ebussû̂d, böyle bir vakfin lüzĥmu/bağlayıcılığı hususunda bir risale yazmış ve birçok yerinde de hataya düşmüş̧ür. Sevap ümidiyle vakıf yapan kimselerin, bu esere güvenmemeleri için, onun kabulü mümkün olmayan yönlerini açıklamak gerekir ki hâkimler de bu görüşlerinin doğruluğuna inarak onun hükümlerine inanmasınlar. Nitekim görüşleri, güvenmeye elverişli değildir ve Kıyamet Günü'nde onların bu konuda herhangi bir mazereti olamaz. Usul ve fürua aykırı, makûl ve menkûl olmaktan uzak ve çelişkilidir. Bu meseleyi, halk için fitne kabul ediyor ve her gücü yeten kişinin de bozması gereken bir münker olarak görüyorum. Fakat ya cahillik, korkaklık veya zaylflı sebebiyle hiçbir kimsenin de, bu işe el atacağını sanmiyorum. Bu sebeple bu münkerden kalemim ve dilim ile nehyetmek benim boynumun borcudur. Çünkü bildiğim halde bu konuda sessiz kalırsam lanetlenmekten korkarım $^{82}$.

Birgivî daha sonra Ebussuûd'un risalesinden alıntılar yaparak her birini tenkit eder. Zamanın sultanının dört mezheb imamının verdiği hükümlere göre ülkeyi idare ettiğini söyleyen Birigvî, Züfer'in bu imamlardan olmadığına dikkat çeker ve onun görüşlerinin tafsilatıyla günümüze gelmediği gibi tabisinin de bulunmadığını vurgular ${ }^{83}$. Keza Züfer'den gelen nakil, vakfın lüzumu (bağlayıcı oluşu) ile değil sadece cevazı ile ilgilidir. İmam Muhammed'in bahsettiği teâruf/örfleşme ise ona göre Hz. Peygamber zamanından müçtehid imamların bulunduğu döneme kadar olan teâruftur ${ }^{84}$. Yoksa herhangi bir asırda müçtehid bulunmayan yerdeki örfleşme değildir. Burada onun verilmiş bir fetvanın müçtehid imamın denetiminden geçmesi gerektiğine olan inacını veya bir müçtehidin görüşlerinden dışarı çıkmamayı hedef alan tavrını görüyoruz. Mehmet Bulut'a göre ekonomik ve siyasi kaygılardan uzak bir bilim adamı olarak Birgivî, vakıfların ve işletme biçimlerinin ehliyetsiz kişilerin elinde ortaya çıkan yanlışlıklarına dikkat çekmişti ${ }^{85}$.

Birgivî’nin para vakfı meselesi dışında öğrenilmesine itiraz ettiği ilimler de vardı. Ona göre tahsil edilmesi yasak olan ilimler, zeki olmayıp kötü niyetli olanlar için kelam ilmi; sihir için kullanılan yıldız (astroloji) ilmidir. Birgivî’nin Kelam ilmine açtı̆̆ 1 parantez şüphesiz ki onun inancı koruma refleksi ile ilgilidir. Zira XVI. asırda Safevî tehlikesi ve Şî̂ tasavvurlara engel olma düşüncesi sadece onun için değil devlet için de temel hareket noktası olmuştur. Kelam ilmiyle zeki, dindar ve ciddi kimselerin meşgul olması gerektiği kanaatindedir. Yıldız ilmini ise namaz vakitleri ve kıbleyi tayin edecek kadar öğrenmelidir. Hendese ilmini tahsil etmek ona göre meşru iken felsefe ve mantık ilimleri kelam içinde düşünülmelidir. K1saca Kelam öğrenecek olanlar için geçerli kriteler burada da esastır. Netice itibariyle Kelam ilmini sadece samimi ve zeki kimseler tahsil edebilecektir ${ }^{86}$. Benzer biçimde ilahiyât (teoloji) ilimleri onların zararından korunmak ve onların batıl olanlarına cevap vermek gayesiyle öğrenilebilir. Burada Birgivî’nin felsefe ile ilahiyâtı ayırması dikkat çekicidir. Felsefeyi hikmete yakın görürken ilahiyâtı kelamın karşısında mütalaa etmektedir. Tabîiyyâtın da dine aykırı olan kısmı, ilahiyât gibi olup dine aykırı olmayan tabîiyyât tahsil edilebilir. Birgivî’ye göre tıp ilmi de müstehab bir ilimdir. Zira tedavi olmak vacip değildir ${ }^{87}$. Onun bu tavrı zühd ve tevekkül anlayışıyla izah edilebilir. Hulâsa isimli eserden şöyle bir alıntı yapar: "İshal olan veya göz ağrısına tutulan bir kimse tedavi olmaz da bunun neticesinde zayıf düşer ve ölürse günahkâr olmaz.". Birgivî'ye göre bu fetva ile oruç tutup sonra iftar yapmayan (yani orucu uzatan) ve böylece ölen kimse

\footnotetext{
82 Birgivî, "Hâşiye fî Redd-i Akvâli Ebi's-suûd", s. 249. Krş. Yılmaz Fidan, "Ebussu'ûd’un Fıkhî Meseleleri Çözümlemedeki Metodu", Doktora Tezi, Marmara Üniversitesi, 2007, s. 258-260.

83 Birgivî, "Hâşiye fî Redd-i Akvâli Ebi's-suûd", s. 250.

84 Birgivî’ye göre teâruf-ı küllî ancak icmâ-ı ilmî ile meşrulaşır. Örfleşmeyi genel ve özel (hâss-âmm) olmak üzere ikiye ayırarak halkın örfü manasındaki özel teârufu ilmî hüccet saymaz. Birgivî, "Hâşiye fî Redd-i Akvâli Ebi's-suûd", 261-266.

85 Mehmet Bulut, "Merkantilstler Karşısında íki Osmanlı Düşünürünün Iktisadi Yaklaşımları" Birgivî Mehmet Efendi ve Kınalızade Ali Efendi" Birinci Iktisat tarihi Kongresi Tebliğleri -1, (İstanbul: 2010), s. 354.

$86 \mathrm{Krş}$. Khaled el-Rouayheb, Islamic Intellectual History in the Seventeenth Century Scholarly Currents in the Ottoman Empire and the Maghreb, (Cambridge University Press, 2015), 17.

87 Birgivî, Tarîka (Nedvî), s. 115-120. Krş. Özkan, Muhammed Birgivî́nin Fıkhî Meselelere Yaklaşımı, s. 66.
} 
arasında fark vardır. Zira zayıf düşmeyecek kadar yemek farzdır. Bunu terk ederse kişi nefsini telef etmiş olur. İlaç kullanmak ise Birgivî’ye göre böyle olmayıp ilaçla sağlığa kavuşmak kesin değildir. Onun bu konudaki temel ilkesi kesin sebepleri terk etmenin tevekkül olmadığıdır ${ }^{88}$. Sihir ve tılsım gibi günah olan ilimleri bunlardan korunmak için tahsil etmenin caiz olduğu görüşünde olan Birgili Mehmed Efendi'nin bu konuda klasik görüşü tekrarladığı anlaşılmaktadır. Birgivî’nin ilimler tasnifinde kendinden önceki klasik sınıflamalara pek itibar etmediğini de kaydetmeliyiz ${ }^{89}$. Tarîka' da dikkat çeken bir tavır da ahlakî kavramların tanımlarında neredeyse tamamen Seyyid Şerif Cürcanî'nin (ö. 1413) Tarifât'ının kullanılmasıdır. Cürcanî, bu eserinde her bir kavrama birkaç tanımlama yapmakta özellikle son yapacağı tanımda "Ehl-i hakk der ki" diyerek mensubu olduğu irfanî Nakşî geleneğin izahlarını aktarmaktadır ${ }^{90}$. Birgivî’nin Tarîka' ya aktardığı tanımlar ise çoğunlukla bunlardır.

\section{Sonuç}

Bürokrat ulema ile bu kulvarda yer almayan alimlerin tavırlarının bazı başlıklarda ayrıldığı bilinmektedir. Ebussuûd'un devlet sorumluluğu yüklü kimliği elbette fetvalarını etkilediği, onunla vasiyyetsiz para vakfı konusunda münakaşaya giren Birgivî'nin ise böyle bir sorumluluktan azade hareket ettiği açıktır. Çivizade ile Birgivî de bu bakımdan kısmen farklılaşmaktadır. Birgivî'nin mizaç itibariyle sert ve haksızlığa tahammül eşiğinin düşük olduğu göz önüne alınırsa niçin devlet memurluğuna mesafeli ve siyasete karşı dikkatli bir alim olduğu anlaşılmaktadır. Atâullah Efendi'ye yazdığı tahmin edilen mektupta ulemanın, vüzera ve diğer idarecilerin işlerine karışmanın yanlışlığını ve isabetsizliğini açıkça ortaya koymuştur. Birigvî’ye göre ulemanın vazifeli bulunmadığı devlet işlerine karışması hem o vazifedekileri rahatsız edecek hem de alim kimliği ile bağdaşmayacak ve onu kıymetsizleştirecektir. Sokullu Mehmed Paşa'ya yaptığı ikaz veya çocuklarına bıraktığı vasiyete bakılırsa onun siyasete mesafesi hayatındaki temel ilkelerden biridir. Bu durum onun kassâm-1 askerîlik görevi sırasında edindiği tecrübe ile alakalı olmalıdır. Birgivî’nin ilimler tasnifi ise klasik sınıflamalardan farklılaşsa da özellikle Gazzalî fikirlerine yakın olduğu anlaşılmaktadır. Zaten Tarîka esasen İhyâ'nın bir yansıması olarak gözükmektedir. Onun ahlakçı kimliği esasen Tarîka' da net olarak gözükmekle birlikte bunun sadece teoride kalmadığı ve onun günlük hayatında da söylediklerini tatbik ettiği anlaşılmaktadır. Bununla birlikte Tarîka'da verilen ahlakî kavramlar, büyük oranda Seyyid Şerif Cürcanî'nin Tarifât'1ndaki Ehl-i hakk denilen tasavvuf ehlinin açıklamalarıyla tanımlanmıştır. Bu nedenle onun tasavvufî geleneğe zühdü aşan bir biçimde bağlı olduğu söylemek yanlış olmamalıdır. Birgivî’nin XVI. yüzyıl Osmanlı düşüncesine en büyük katkısı şüphesiz ki Tarîka'da ortaya koyduğu ahlak felsefesi ve halkı anlayabileceği tarzdaki sunumudur. Öyle ki tereke defterlerine bakıldığında neredeyse her defterde bir Tarîka bulmak mümkündür. Onun bu durumu İhyâ ve Şiratü'l-İslam gibi eserlerle birlikte anılmasını temin etmektedir. Vasiyyetsiz para vakfının, onu siyaset ve idareyle karşı karşıya getiren temel konulardan olduğu açıktır. Kendisinden önce Çivizâde bu meselede konuşmuş ve bir ferman ile yasak getirtmiş olsa da 1548 tarihli diğer bir ferman ile para vakfı uygulamasına tekrar izin verildiği kaydedilmiştir. Birgivî bu konuda da Ebussuûd'a bir reddiye yazarak siyaset ve idarenin uygun gördüğü her şeyin fikhen uygun olmayabileceğini söylemiştir.

\footnotetext{
88 Birgivi, Tarîka (Taha), s. 74.

89 Lütfü Cengiz, "Birgivî’de ilimler Sınıflandırması", Balıkesirli Bir İslam Alimi Imam Birgivî, Ed. Mehmet Bayyiğit vd. (Balıkesir: 2021), III, (145-151), s. 151.

90 Seyyid Şerif Cürcanî, Tarifât, (Beyrut: Dârun-Nefais, 2017), 123, 150, 184, 195. Ayrıca bkz. Osman Cengiz, "Birgivî Metinlerinde Cürcanî Etkisi ve İrfanî Muhteva" Balıkesirli Bir İslam Alimi Imam Birgivî, Ed. Mehmet Bayyiğit vd. (Balıkesir: 2021), III, 345-353.
} 


\section{Kaynakça}

Afyoncu, Erhan, Ahmet Önal ve Uğur Demir, Osmanlı Imparatorluğu’nda Askerî İsyanlar ve Darbeler, İstanbul: Yeditepe Yayınları, 2016.

Akgündüz, Ahmet, Osmanl Kanunnameleri (I-XI) İstanbul: FEY vakfi-OSAV, 1990-2016.

Andican A. Ahat, "Tüzükât-1 Timurî Gerçek mi ve Geçerli bir Birincil Tarihî Kaynak Olarak Kullanılabilir mi?” Türkiyat Mecmuasl, c. 27/2, 2017, 33-83.

Arslan, Ahmet Turan, “İmam Birgivî’nin (929-9818/1523-1573) Bir Mektubu”, İlmî Araştırmalar, Sayı 5, 1997, ss. 61-74

Atâî, Zeyl-i Şekâyık, İstanbul: 1268.

Atç11, Abdurrahman, Procedure in the Ottoman Court and the Duties of Kadis, The Institute of Economics and Social Sciences of Bilkent University, Department of History, Ankara: 2002.

Aydın, Ahmet, “Çivizâde Muhyiddin Mehmed Efendi'nin Fıkhî Görüşleri ve Fetvâları”, Yüksek Lisans Tezi, Marmara Ünviversitesi, 2006.

Bağdâdî İsmail Paşa, Hediyyetü'l-Ârifin Esmâü'l-Müellifîn ve Âsâru'l-Musannifìn (I-II) Beyrut: 1955.

Bağdadî İsmail Paşa, İzahu 'l-Meknun fi-z-Zeyl ala Keşfiz-Zunûn an Esamil-Kutub ve'l-Funûn (I-II) Beyrut: Dâru ihyâi'-t-türâs el-arabî.

Barçın Mustafa, “Ünlü Alim İmam Birgivî” Sebîlürreşâd, Cilt XIV, Sayı 329, s. 59.

Bilgin, Vejdi, Fakih ve Toplum-Osmanlı'da Sosyal Yapı ve Fıkıh, İstanbul: İz Yayınları, 2003.

Birgivî Mehmed Efendi, Risâle-i Birgivî, İstanbul: 1261.

Birgivî Mehmed Efendi, İm 'ânü'l-Enzâr, Dersaadet: Ahmed Kâmil Matbaası, 1331

Birgivî Mehmed Efendi, Risâletü İnkâzi'l-Hâlikîn, thk ve tlk. Hüsâmuddin bin Musa Affâne, Kudüs: Câmiatü'l-kuds, 2002.

Birgivî Mehmed Efendi, “es-Seyfü's-Sârim”, Resâilü'l-Birgivî, Beyrut, 2011.

Birgivî Mehmed Efendi, “İnkâzu'l-Hâlikîn”, Resâilü’l-Birgivî, Beyrut, 2011.

Birgivî Mehmed Efendi, et-Tarîkakü'l-Muhammediyye, thk. Muhammed Rahmetullah Hafiz en-Nedvî, Dimaşk, 2011.

Birgivî Mehmed Efendi, XVI. Asır Osmanlısında Bir Âlimin Kaleminden Siyaset Eleştirisi: Birgivî ve "Zühru'l-Mülûk” Adlı Eserinin Tercümesi, neşr. Huriye Mart1-Ahmet Ürkmez, ÇÜİFD, cilt: 15, sy. 2, 2015, 1-28.

Birgivî Mehmed Efendi, Tarikat-1 Muhammediyye, terc. Muhammed Taha, İstanbul, 2013.

Birgivî Mehmed Efendi, "Hâşiye fî Reddi Akvâli Ebussuûd”, Resâilü'l-Birgivî, Beyrut, 2011.

Bulut, Mehmet, "Merkantilstler Karşısında İki Osmanlı Düşünürünün İktisadi Yaklaşımları" Birgivî Mehmet Efendi ve Kınalızade Ali Efendi” Birinci İktisat tarihi Kongresi Tebliğleri -1, İstanbul: 2010.

Cengiz, Lütfü, "Birgivî'de ilimler Sınıflandırması", Balıkesirli Bir İslam Alimi İmam Birgivî, Ed. Mehmet Bayyiğit vd. (Balıkesir: 2021), III, (145-151)

Cengiz, Osman, 16. Yüzyıl Osmanlı Düşüncesinin Kaynakları: Çivizade Ebussuûd Birgivî, (İstanbul: Ketebe Yayınlar1, 2019). 
Cengiz, Osman, "Birgivî Metinlerinde Cürcanî Etkisi ve İrfanî Muhteva" Balıkesirli Bir İslam Alimi İmam Birgivî, Ed. Mehmet Bayyiğit vd. (Balıkesir: 2021), III, 345-353.

Dağlar, Abdülkadir, "Türkçe Mektupları Işığında Ebussuûd Efendi'nin Beşerî Münâsebetleri”, Osmanlı Araştırmalarl / The Journal of Ottoman Studies, XLI (2013), 279-320.

Demir, Abdullah, Devlet-i Aliyye'nin Büyük Hukukçusu Şeyhülislâm Ebussu'ûd Efendi, İstanbul, Ötüken Yayınları, 2006.

Düzdă̆, M. Ertuğrul, Ebussu' ûd Efendi Fetvaları Işığında 16. Asır Türk Hayatı, İstanbul: Enderun Kitap, 1983.

Düzenli, Pehlül, “Osmanlı Hukukçusu Ebussuûd Efendi ve Fetvaları”, Doktora Tezi, Selçuk Üniversitesi, Konya: 2007.

Ebussuud, Duâname-i Ebussuûd, İBB, Atatürk Kitaplı̆̆g, Belediye, K0792, 5a-5b, 14b.

Gelibolulu Mustafa Âlî, Künhü’l-Ahbar, Tıpkı Basım, Ankara: Kültür Bakanlığı, 2009.

Şimşek, Halil İbrahim, “Anadolu Müceddidîlerine İlişkin Bazı Tarihî Bilgilerin Kullanılışı Üzerine Bir Değerlendirme”, Gazi Üniversitesi Çorum İlahiyat Fakültesi Dergisi I/2, 2002/2, 222.

Imber, Colin (2004). Seriattan kanuna Ebussu'ûd ve Osmanlı'da İslami hukuk, (çev. Murteza Bedir), İstanbul: Tarih Vakfi Yurt Yayınları, 2004.

İbnü'l-Edhemî, Mecmûa-i fetâvâ, Süleymaniye Ktp. Atıf Efendi Kütüphanesi, 2835.

İhsanoğlu, Ekmeleddin “Osmanlı Bilimine Toplu Bakış” Osmanlı, 8/21-23.

Ortaylı, İlber, Hukuk ve İdare Adamı Olarak Osmanlı Devleti'nde Kadı, İstanbul: Kronik Yayınları 2016.

İnalcık, Halil, Kuruluş ve İmparatorluk Sürecinde Osmanlı: Devlet Kanun, Diplomasi, İstanbul: Timaş Yayınları, 2019.

İpşirli Mehmet, “Osmanlı Uleması” Osmanl, Ankara: Yeni Türkiye Yayınları, 8/71, 1999.

Kanat, Cüneyt, Ortaçağ Türk Devletlerinde Suç ve Ceza, İstanbul: Küre Yayınları, 2017.

Katharina Anna Ivanyi, Virtue, Piety and the Law: A Study of Birgivī Mehmed Efendī's al-Tarīqa alMuhammadiyya, the Degree of Doctor of Philosophy, November 2012.

Katip Çelebi, Mizânü'l-Hak fì İhtiyâri'l-Ehakk: İslam'da Tenkit ve Tartışma Usulü, Sad. Süleyman Uludağ Mustafa Kara, İstanbul: Marifet Yayınları, 2001.

Şahin, Kaya, Kanunî Devrinde Imparatorluk ve İktidar: Celalzade Mustafa ve 16. Yüzyıl Osmanlı Dünyası, çev. Ahmet Tunç Şen, İstanbul: Yapı Kredi Yayınları, 2014.

Lekesiz, M. Hulusi, "XVI. Yüzyıl Osmanlı Düzenindeki Değişimin Tasfiyeci (Püritanist) Bir Eleştirisi: Birgivî Mehmet Efendi ve Fikirleri”, Doktora Tezi, Hacettepe Üniversitesi, 1997.

Lekesiz, M. Hulusi, “Osmanlılarda Sünnî-Hanefî Geleneğin Oluşmasında Ulemanın Rolü”, Osmanlı, Güler Eren, (ed.), (Ankara: Yeni Türkiye Yayınlar1, 1999), 8/80-84.

Mart1, Huriye, Birgivî Mehmed Efendi, Ankara: TDV Yayınları 2011.

Midilli Muharrem, “Klasik Osmanlı Hukukundaki Şer'-Örf Ayrımına Dair Modern Tartışmalar”, Türkiye Araştırmaları Literatür Dergisi, Cilt 12, Say1 23, 2014, 33-48

Mumcu, Ahmet, Osmanlı Devleti’nde Siyaseten Katl, İstanbul: Phoenix Yayınları, 2017.

Mustafa Öztürk “Zülkarneyn” TDV İslam Ansiklopedisi, 44/564. 
Ocak, Ahmet Yaşar, Osmanlı Sufiliğine Bakışlar, İstanbul: Timaş Yayınları, 2011

Ocak, Ahmet Yaşar, Yeniçağlar Anadolu’sunda İslam’ın Ayak İzleri: Osmanlı Dönemi, İstanbul: Kitap Yayınevi, 2012.

Ortaylı, İlber, Hukuk ve İdare Adamı Olarak Osmanlı Devleti'nde Kadı, İstanbul: Kronik yayınları, 2016.

Ortaylı, İlber "Kad1" TDV İslam Ansiklopedisi, XXIV, 70.

Özkan, Mehmet, XVI. Yüzyıl Osmanlı Alim ve Fakihi Muhammed Birgivî’nin Fıkhî Meselelere Yaklaşımı, Bursa: Emin Yayınlar1, 2016.

Özkan, Mehmet, Balıkesirli Bir Osmanlı Alimi: Sarı Gürz Nureddin Hamza Efendi (ö.928/1522) ve elMurtazâ Adlı Eseri”, Milli Mücadele’nin 100. Yılında Kuva-yı Milliye Şehri Balıkesir Uluslararası Sempozyumu Bildiri Kitabı (19-22 Eylül 2019), Editörler: Prof. Dr. Zeki Çevik, Prof. Dr. Kamile Gülüm, Prof. Dr. Birsel Oruç Aslan, Arş. Gör. Hasret Ulusoy Yıldırım, Balıkesir Büyükşehir Belediyesi Kent Arşivi Kültür Yayınları No: 16/2, Nisan 2020, c.II, s. 504.

Özkan, Mehmet, “Osmanlıca Metinlerde İslam Hukuku Motifleri: Fetâvâ-yı Birigivî Örneği”, Balıkesir Üniversitesi İlahiyat Fakültesi Dergisi Journal of Balikesir University Faculty of Theology, Cilt 1, Say1 1, Hazran 2015, (ss.79-107), 95.

Özkan, Mehmet “Osmanlı'da İlmihal Geleneği: Kadızâde Mehmed Efendi (1045/1635) ve "Risâle-i Kadızâde” Adlı Çalışması” İslam Hukuku Araştırmaları Dergisi, Sayı: 27 Nisan 2016, 561.

Öztürk, Yücel “Osmanlı Klasik Sisteminin Teşekkülü ve Çözülüşü” Türkiye Günlüğü, Sayı 58, KasımAralık, 1999, 133-149.

Peçevî Tarihi, haz., Bekir Sıtkı Baykal, Ankara: Kültür Bakanlı̆̆g Yayınları, 1992.

Rouayheb Khaled, Islamic Intellectual History in the Seventeenth Century Scholarly Currents in the Ottoman Empire and the Maghreb, Cambridge University Press, 2015.

Sariyannis, M., Ottoman Political Thought up to The Tanzimat: A Concise History, Foundation for Research and Technology-Hellas-Institute for Mediterranean Studies Rethymno, 2015

Schacht Joseph, İslam Hukukuna Giriş, çev. Mehmet Dağ-Abdülkadir Şener, Ankara, 1986

Seyyid Şerif Cürcanî, Tarifât, Beyrut: Dârun-Nefais, 2017.

Şehabeddin, M. C. “Tekindăg, Yeni Kaynak ve Vesikaların Işı̆̆ı Altında Yavuz Sultan Selim'in İran Seferi”" IÜ̈ Edebiyat Fak. Tarih Dergisi, c.XVII, s.22, Mart, 1967, 54-55.

Tuna, Korkut “Osmanlı Batılılaşma ve Bilimler” Osmanlı, Yeni Türkiye Yayınları, VIII, 56-57.

Tursun Bey, Târih-i Ebu'l-Feth, haz., Mertol Tulum, İstanbul: İstanbul Fetih Cemiyeti, 1977.

Türkan, Mustafa, Hicri Altıncı Asır Hanefî Nevâzil Edebiyatı, Ankara: İlahiyat Yay., 2020.

Ünal, Mehmet Ali, Osmanlı Müeseseleri Tarihi, Isparta: Fakülte Kitabevi, 2017.

Yılmaz, Hüseyin, “Osmanlı Tarihçiliğinde Tanzimat Öncesi Siyaset Düşüncesine Yaklaşımlar” Türkiye Araştırmaları Literatür Dergisi, Cilt 1, Sayı 2, 2003, (231-298), 289-290.

Yüksel, Emrullah, Mehmed Birgivî’nin Dinî ve Siyasî Görüşleri, Ankara: Türkiye Diyanet Vakfı Yayınları, 2011. 